\title{
GOVERNMENT REGULATION OF RADIO PROGRAM FORMAT CHANGES
}

\author{
Dantel L. Brenner $\uparrow$
}

"[I]n order to progress," Edward Roscoe Murrow once observed of radio, "it need only go backward." 1 For better or worse, however, radio has not gone backward to the days when one could find an expansive range of program selections on most stations, from the vaudeville acts of the Maxwell House Showboat to the mysteries of Eno Crime Clues, from the dramas of Soconyland Sketches to the discussions convened around The University of Chicago Round Table. ${ }^{2}$ These radio shows, and the programming philosophy that generated them, became extinct by the late nineteen-fifties, when television replaced radio as the dominant medium reaching the private home. Since then, radio stations generally have limited the scope of their programming and emphasized particular program formats in order to reach specialized audiences. ${ }^{3}$ These format decisions generally supersede all other considerations in determining a station's identity and audience in the advertising marketplace. ${ }^{4}$

† A.B., A.M., 1973, Stanford University; J.D., 1976, Stanford Law School. Nember, District of Columbia, California Bars.

This Article grew out of a paper written for a seminar on Economics and Freedom of Expression conducted by Bruce Owen at the Stanford Law School in 1976. Subsequent to writing it, I have become an associate with a law firm which is involved in litigation in this area. I have not participated in any aspect of that litigation. The views presented here are mine alone. I wish to express appreciation to Professor Owen for his helpful comments on earlier drafts of this Article; errors which remain are due to my perversity, not to Professor Owen's oversight.

1 Address by Edward R. Murrow, Radio \& Television News Directors Association (Oct. 15, 1958), reprinted in part in A. Kendruck, Preme Tame 413 (1969).

2 See 2 E. Barnouw, A History of Broadcasting in the UntTed States, The Golden Web 6, 60 (1968).

3 See Hirsch, The Economics of Rock, 210 Natron 275 (1970).

4 The change in character of radio broadcasting in the United States has been matched by tremendous growth. In 1945 there were 884 standard (AM) commercial stations, 46 FM commercial stations, and no noncommercial FM stations. By 1955, the numbers had grown to 2,669 AM, 552 FM commercial, and 122 FM noncommercial stations. In 1977 the numbers swelled to 4,497 AM, 2,873 FM commercial, and $870 \mathrm{FM}$ noncommercial stations. The $A B C^{\prime}$ 's of Radio and Television, [1978] Broadcasting Y.B. A-I, A-7. The slower growth of FM radio before World War II was due in part to a lack of knowledge of its advantages (principally no reflection back to earth of station signals, thereby allowing many FM stations to use the same frequency without interference) even though the theory of FM signals had been known for some time. FM radio has emerged as a major, if not dominan!, force. Today, more FM stations than AM stations figure among the top ten stations in the top 50 markets (260 out of 500). Broadcasting, July 24, 1978, at 48-57. 
The emphasis on format by broadcasters, advertisers, and the public creates a regulatory issue for the Federal Communications Commission ("Commission," "FCC") when a radio station licensee seeks to change from one format to another. Most frequently, this situation arises when a potential transferee of the current radio licensee believes that a different format would be more profitable to the proposed venture. The decision to steer a business acquisition onto a more profitable course would ordinarily lie within the province of private decision-making. When the business venture consists of broadcasting, however, this decision, because it must be described in the license transfer application, is subject to scrutiny by the FCC in order to insure that it is in the "public interest." 5 These transfers have stirred controversy when their proposed format changes would cause the abandonment of a nonduplicated entertainment format. Termination of a community's only classical or progressive rock broadcast service has provoked citizens to oppose FCC approval of the proposed change on the ground that such a change is contrary to the public interest. ${ }^{6}$

The standard for administrative approval of transfers involving the loss of nonduplicated formats is presently the cause of a fundamental conflict between the Commission and the Court of Appeals for the District of Columbia Circuit. In Citizens Committee to Save WEFM v. FCC, ${ }^{7}$ an appeal involving a license transfer and format change for a Chicago classical music station, the circuit court rejected the Commission's out-of-our-hands approach to format changes and ordered the agency to consider actively the desirability of the proposed change. While following the court's directive in the instant case, the FCC subsequently announced a policy in direct opposition to the court's approach. ${ }^{8}$ The disagreement between the court and the FCC is not limited to considerations

For a general history of radio broadcasting in the United States, see 2 E. BARNouw, supta note 2; 3 E. Barnouw, A History of Broadcasting in the United States, THE IMAGe EMPIRE (1970).

647 U.S.C. $\$ 310$ (d) (Supp. V 1975):

No construction permit or station license, or any rights thereunder, shall be transferred, assigned, or disposed of in any manner, voluntarily or involuntarily, directly or indirectly, or by transfer of control of any corporation holding such permit or license, to any person except upon application to the Commission and upon finding by the Commission that the public interest, convenience, and necessity will be served thereby.

6 See, e.g., Citizens Comm. to Keep Progressive Rock v. FCC, 478 F.2d 926 (D.C. Cir. 1973); Citizens Comm. to Preserve the "Voice of the Arts in Atlanta on WGKA-AM and FM" v. FCC, 436 F.2d 263 (D.C. Cir. 1970).

7.506 F.2d 246 (D.C. Cir. 1974).

8 Changes in the Entertainment Formats of Broadcast Stations, 60 F.C.C.2d 858 (1976) [hereinafter cited as Format Policy Statement]. 
of administrative policy; it also reflects their diverging theories of the economics of format change. The Commission posits a theory based on marketplace forces, while the court claims that the dynamics of the free market inadequately protect the public interest.

This Article endeavors to demonstrate that neither the court of appeals' view nor the FCC's laissez-faire solution constitutes a workable approach to resolving format change cases. First, by referring to models developed by economist Peter Steiner, this Article considers whether a system of free competition is more likely to produce greater duplication of entertainment formats than is a non-free market approach, as the court of appeals intimates. Second, it reviews the practical difficulties that would confront the FCC if the agency attempted to implement the court's prescribed manner of regulation. Third, it questions the FCC's conclusion that virtual abandonment of radio format regulation is the "best available means" 9 to dispose of these cases. Fourth, it sets forth and evaluates a proposed regulation, based on an economic model of the transfer challenge process, to dispose of format cases by providing incentives for settlement prior to hearing. Preliminarily, however, a rehearsal of the circumstances and conflicting resolutions of the WEFM decision is necessary.

\section{The WEFM GASE}

Since its first day on the air in 1940, WEFM had been the mainstay of classical music broadcasting in the Chicago area. ${ }^{10}$ It was not surprising, therefore, that some of WEFM's listeners strenuously objected when GCC Communications of Chicago, Inc., the proposed license transferee, announced in 1972 that it intended to change the station's format to rock music if its application for assignment of WEFM's license was approved.11 The existing licensee, Zenith Radio Corporation, alleged that it had consistently lost money while broadcasting with a classical format, ${ }^{12}$ and the pro-

9 Id. 863. 1974).

10 Citizens Comm. to Save WEFM v. FCC, 506 F.2d 246, 262 (D.C. Cir.

11 Id. 254 \& nn.3 \& 4. Interestingly, GCC, the proposed transferee, originally intended to present a format of rock music for only $70 \%$ of a 24-hour broadcast day. Id. Hence, it conceivably could have maintained a classical music format for about $30 \%$ of its broadcast day. See notes 128, 129, 159 infra \& accompanying text.

12 Citizens Comm. to Save WEFM v. FCC, 506 F.2d 246, 255 (D.C. Cir. 1974). Zenith had broadcast for more than two decades without commercials; in 1966 it started to accept advertising. Id. 253-54. 
posed transferee believed that the format change would solve the station's financial problems. ${ }^{13}$

A group of dismayed listeners organized the Citizens Committee to Save WEFM and petitioned the FCG to deny the transfer on the ground that substantial factual disputes existed about the asserted justifications for the format change. These disputes centered on whether WEFM's service area would in fact lose its only classical station, whether Zenith's claimed losses were due to poor management or the noncommercial appeal of the format, and whether the proposed transfer violated Zenith's promise in its 1970 renewal application to continue WEFM's classical format. ${ }^{14}$ The FCG dismissed the petition, ${ }^{15}$ but in 1974 the Court of Appeals for the District of Columbia Circuit, after initially upholding the agency's determination, reversed the FCG en banc in Citizens Committee to Save WEFM v. FCG. ${ }^{16}$ The court also remanded the case for reconsideration of the issues raised by the committee in conformity with guidelines specified by the court. The court held that the FCC "must affirmatively consider" whether the public interest is served by approving a proposed assignment when it involves the loss of a unique format. ${ }^{17}$ This affirmative inquiry may necessitate a public hearing if there are "substantial questions of fact or inadequate data in the application or other officially noticeable materials." 18 Further, the court found that the mere assertion that

13 Id. 255.

14 Id. 254-55.

15 Zenith Radio Corp., 38 F.C.C.2d 838 (1972). This order also denied the relief requested in a complaint filed by the Committee while its petition was being considered. The Committee had asked the Commission to dedicate WEFM to classical music programming as long as a qualified licensee was willing to operate it for that purpose and the listening audience remained interested in such programming. Id. 847-48. Four of the seven commissioners joined in the opinion, a fifth joined in the result, one did not participate, and one, Nicholas Johnson, dissented.

The Commission denied the Committee's petition for reconsideration. Zenith Radio Corp., 40 F.C.C.2d 223 (1973). Six commissioners issued a separate statement that endorsed a marketplace approach to the format problem, but added that nonduplicated format cases would justify "an extra hard look" before approval would be granted. Id. 231. This approach was echoed by Commissioner Fogarty years later. See Changes in the Entertainment Formats of Broadcast Stations, 66 F.C.C.2d 78, 86 (1977) (Fogarty, Comm'r, concurring); McCormick Communications, Inc., [1978] 42 RAd. REG. 2d (P \& F) 989, 995 (Fogarty, Comm'r, concurring); cf. Action for Children's Television v. FCC, 564 F.2d 458, 479 (D.C. Cir. 1977) (In a rule-making context, the court required the FCC to take "a hard look" . . . at the relevant issues." (footnote omitted)):

16506 F.2d 246 (D.C. Cir. 1974).

17 Id. 262. This affirmative consideration is based on the premise that "[t]here is a public interest in a diversity of broadcast entertainment formats." Id. However, for a refutation of that premise, see notes 51-56 infra \& accompanying text.

18 Citizens Comm. to Save WEFM v. FCC, 506 F.2d 246, 262 (D.C. Cir. 1974). In the instant case, the court found that two questions raised by the Committee were 
losses were due to a nonduplicated format would not justify a change unless the losses were attributable to the format itself. ${ }^{19}$

The FCG responded to the court's directives in two ways. First, the Commission complied with the court's mandate and remitted the WEFM dispute to an administrative law judge for a hearing consistent with the court's order. ${ }^{20}$ Second, it issued a Notice of Inquiry ${ }^{21}$ announcing the Commission's intention to reformulate its entertainment format policy in a manner likely to deviate from the approach taken by the court of appeals. ${ }^{22}$ Three months later, in Changes in the Entertainment Formats of Broad-

substantial and material and thus required a hearing to resolve them: whether Zenith actually incurred the losses it claimed and whether GCC had misled the FCC when it asserted that it did not decide to change the station's format until extensive surveys indicated such a change was advisable. Id. 265-66. The court found that a third question, the adequacy of an alternative classical music station in WEFM's service area, also had to be resolved, but left the method of resolution to the FCC's discretion. Id. 262-65.

10 Id. 262. Zenith claimed "to have incurred an operating loss of almost $\$ 2$ million in the six years during which WEFM sold advertising time, and to have suffered a net after tax loss of approximately $\$ 1$ million." Id. 265 (footnote omitted).

20 The administrative law judge found for GCC on the issues of nonuniqueness of WEFM's format in its service area, losses sustained by Zenith, and misrepresentation to the Commission. Zenith Radio Corp. (Initial Decision), Mimeo No. 71290, Docket No. 20581 (Aug. 20, 1976). The day the initial decision was issued, however, the FCC Review Board ordered enlargement of the hearing to include the issues whether GCC was trafficking in the WEFM license (buying and selling for the sole purpose of making a profit) and had kept its application up to date in accordance with 47 C.F.R. \$1.65 (1972). Zenith Radio Corp., 60 F.C.C.2d 1012 (1976). The administrative law judge again found in favor of the applicant, Zenith Radio Corp., Mimeo No. 88656, Docket No. 20581 (Sept. 2, 1977). On October 27, 1977, after the supplemental decision issued but prior to its Commission review, GCC and the Citizens Committee reached a settlement agreement. In exchange for the Committee's withdrawing its objection to the transfer, GCC promised to reimburse it $\$ 60,000$ for legal expenses and to contribute funds and WEFM's record library to two other Chicago stations, WNIB and WBEZ-FM, to enhance their classical music offerings. The Commission granted GCC's motion for adoption of the initial decisions, Zenith Radio Corp., [1978] 42 RAD. Reg. 2d (P \& F) 472, and GCC assumed control of WEFM.

21 Changes in the Entertainment Formats of Broadcast Stations (Notice of Inquiry), 57 F.C.C.2d 580 (1976).

22 One explanation for the notice of inquiry inviting discussion of a possible reformulation of FCC policy was the six years of inconsistency, 1970-1975, between it and the Court of Appeals for the District of Columbia Circuit in resolving format change disputes in connection with sales of radio stations. See Citizens Comm. to Keep Progressive Rock v. FCC, 478 F.2d 926 (D.C. Cir. 1973); Hartford Communications Comm. v. FCC, 467 F.2d 408 (D.C. Cir. 1972); Citizens Comm. to Preserve the Present Programming of WONO(FM) v. FCC, No. 71-1336 (D.C. Cir. May 13, 1971); Citizens Comm. to Preserve the "Voice of the Arts in Atlanta on WGKA-AM and FM" v. FCC, 436 F.2d 263 (D.C. Cir. 1970). The ultimate rejection by the Commission of the court's approach was foreshadowed in Changes in the Entertainment Formats of Broadcast Stations (Notice of Inquiry), 57 F.C.C.2d at 584, and in Chairman Wiley's separate statement in which he wrote "[b]ased on the arguments I have heard to date, I do not believe that there is any objective or principled ground for agency decision-making in the format area." 57 F.C.C.2d at 586 . 
cast Stations ("Format Policy Statement") ${ }^{23}$ the Commission declared that; henceforth, the economic forces of the marketplace rather than its own regulatory expertise would control the selection of radio formats. ${ }^{24}$ In effect, radio advertisers, who sponsor commercial programming, would be allowed to determine the array of format choice available in a particular market, and those determinations would be conclusively presumed to be in the public interest. The FCG did acknowledge that the advertisers' choices do not directly reflect the listeners' preferences. ${ }^{25}$ Nonetheless, the FCC decided with one dissenting vote ${ }^{2 B}$ that forces created by advertisers furnish the "best available means of producing the diversity to which the public is entitled," ${ }^{27}$ particularly in light of the administrative burdens involved in the public hearings contemplated by the court. 28

Curiously enough, the FCC and the court of appeals arrived at their resolutions of the nonduplicated format issue in a situation (or, for the Commission, on the heels of one) in which the threatened format may actually have been duplicated in the market. The

23 Format Policy Statement, supra note 8. Petitions for reconsideration were filed by several citizen groups, but the Commission rejected them and decided instead to adhere to its previous opinion in the Format Policy Statement. Changes in the Entertainment Formats of Broadcast Stations, 66 F.C.C.2d 78 (1977). The Commission stated it was "fully cognizant of the fact that an administrative agency is not authorized to override or reverse a mandate of the Court of Appeals" and "hoped" that its Format Policy Statement would "provide a helpful basis for further judicial consideration." Id. 79. It added that implementation of the new policy would be stayed pending final disposition of court review. Id. 85. Several citizen groups petitioned for review by the Court of Appeals for the District of Columbia Circuit. WNCN Listeners Guild v. FCC, Nos. 76-1692, 76-1793, 77-1951 (D.C. Cir. July 28, 1976). The scope-of-review aspects of the appeal are discussed in Tannenwald \& Auckenthaler, Changes in Radio Entertainment Formats, 21 ST. Louss U.L.J. 358, 364-65 (1977).

24 The evidence on this record supports the conclusion that the marketplace is the best way to allocate entertainment formats in radio, whether the hoped for result is expressed in First Amendment terms (i.e., promoting the greatest diversity of listening choices for the public) or in economic terms (i.e., maximizing the welfare of consumers of radio programs).

Format Policy Statement, supra note 8, at 863. Cf. Home Box Office, Inc. v. FCC, 567 F.2d 9, 42 n.73 (D.C. Cir.), cert. denied, 98 S. Ct. 111 (1977): "[T] Commission may not assume that enhancement of competition is beneficial to the public interest unless it has examined the consequences for the interest of listeners and viewers." The Commission has stayed implementation of its marketplace approach until judicial review of the Format Policy Statement is concluded. See, e.g., Stockholders of Rust Communications Group, Inc., 64 F.C.C.2d 883, 886 n.3 (1977). infra.

25 Format Policy Statement, supra note 8 , at 863; sce text following note 56

26 Format Policy Statement, supra note 8, at 882 (Hooks, Comm'r, dissenting;.

See text accompanying note 121 infra.

27 Format Policy Statement, supra note 8, at 863.

28 Id. 864-65. 
Commission had initially concluded that the WEFM transfer application did not involve loss of a nonduplicated format. ${ }^{29}$ The court of appeals, however, found that, based on the record before it, the transferee had not demonstrated that any other station in the Chicago area provided a classical format. ${ }^{30}$ Yet, on remand, the Commission found once again that other local stations were adequate substitutes for WEFM. ${ }^{31}$ While it may be that the facts in WEFM provide another example of Holmes' theory about the origins of bad law, ${ }^{32}$ they did bring the disagreement between the court and the Commission into the open.

\section{The WEFM Decision and the Steiner Model}

Because the differing resolutions of the court and the Commission proceed from the economic theories embraced by the decisionmakers, it is appropriate to discuss the substance of the two economic theories that emerged in WEFM and to evaluate their applicability to the radio format problem. Economic models rarely provide an entirely faithful portrait of actual conditions; often they are developed without specific factual circumstances in mind. In this respect, Peter O. Steiner's 1952 model of radio program patterns is distinctive. It describes industry practices in detail and analyzes the practical effects of free competition on format diversity. ${ }^{33}$ As a result, Steiner's analysis and predictions provide a theoretical explanation of the court of appeals' reluctance to rely on free market forces to determine a community's format array.

29 Zenith Radio Corp., 40 F.C.C.2d 223, 225-26 (1973).

30 One of the two stations relied on by the FCC, WNIB, which served the city of license, Chicago, did not reach as broad an audience as WEFM did. Having determined that "the public interest implicated in a format change is the interest of the public in the service area, not just the city of license," Citizens Comm. to Save WEFM v. FCC, 506 F.2d 246, 263 (D.C. Cir. 1974), the court concluded that WNIB was not an available substitute for WEFM. For a discussion of the court's choice of relevant service area, see notes 87-95 infra \& accompanying text. The court, having found that the second station, WFMT, had previously been a "fine arts" instead of a "classical music" station, 506 F.2d at 264-65, concluded that the Commission had not satisfactorily determined WFMT's current status nor the adequacy of a fine arts station as an alternative source of classical music. But see Home Box Office, Inc. v. FCC, 567 F.2d 9, 30 n.49 (D.C. Cir.), cert. denied, 98 S. Ct. 111 (1977) ("At stake was a classical music format provided by only one other station in WEFM's service area."); Citizens Comm. to Save WEFM, 506 F.2d at 254 (committee opposing the change seemed to concede that WFMT was a classical music station). 1976).

81 See Zenith Radio Corp., Mimeo No. 71290, Docket No. 20581 (August 20,

32 Northern Securities Co. v. United States, 193 U.S. 197, 400 (1904) (dissent)

("Great cases like hard cases make bad law.").

33 Steiner, Program Patterns and Preferences, and the Workability of Competition in Radio Broadcasting, 66 Q.J. EcoN. 194 (1952). 


\section{A. Steiner's Model}

Steiner begins with several assumptions about radio as it existed when he developed his theory in the early nineteen-fifties. $\mathrm{He}$ assumes the following facts: ${ }^{34}(1)$ there is a meaningful concept of the period of time in which a broadcaster presents a single program; (2) the costs of program production and distribution are unaffected by the number of individuals who actually choose to listen; (3) although the costs of production do vary within these categories, there are only "high cost" and "low cost" programs; (4) the rates charged by stations for use of time are not a function of the popularity of the program to be offered; (5) except for the opportunity costs of the listener's time, the program is a free commodity for the listener; (6) one and only one unified market area is under consideration; (7) each station seeks to maximize the number of listeners for its program in every period; (8) identifiable program types (the equivalent of formats) exist and a determinate number of listeners will listen to a particular program type if it is offered; (9) the production and presentation of a program does not affect the program preferences of individuals; (10) no listener has second-choice programming and, therefore, if the first choice is not available, he will not listen at all; and (11) the stations simultaneously broadcasting the same type of programming will share equally the available audience for that programming type. Furthermore, although Steiner does not claim that the public's program preferences are in fact skewed, with distinct majority preferences and many minority tastes, he bases his arguments on this type of model. Under these assumptions, Steiner concludes that competition among broadcasters will gravitate toward a duplication of formats, with a tendency to ignore minority tastes in programming, except in those situations in which the number of competing broadcasters is large. Conversely, he reasons that monopoly control will inherently produce a more diverse program mix and satisfy more listeners.

To illustrate, suppose that the listening population of Bullwinkle County consists of four distinct listening groups, each preferring a different format and each, under Steiner's assumption, preferring nonlistening to listening to one of the three other formats. Suppose further that the population is skewed so that listeners in Group II total less than half of those in Group I, and listeners in Group III are substantially fewer in number than

34 Id. 195-99. Of these 11 assumptions, the last six are substantially modified or relaxed later in Steiner's article. Id. 217-18. 
those in Group II but are in turn substantially more numerous than those in Group IV.

\section{TABLE I. FORMAT PREFERENCES OF BULLWINKLE RADIO LISTENERS}

$\begin{array}{lcccc}\begin{array}{l}\text { Listener Group } \\ \text { Preferred Format }\end{array} & \begin{array}{c}\text { I } \\ \text { Top 40 }\end{array} & \begin{array}{c}\text { II } \\ \text { Classical }\end{array} & \begin{array}{c}\text { III } \\ \text { All } \\ \text { News }\end{array} & \begin{array}{c}\text { IV } \\ \text { Religious }\end{array} \\ \begin{array}{l}\text { Number of Listeners } \\ \text { in Each Group }\end{array} & 600 & 250 & 175 & 115 \\ \text { (Total = 1140) } & & & & \end{array}$

If pure competition determines format choice, then with each successive channel assignment the market would contain the following formats and listenerships:

\section{TABLE II. FORMAT CHOICES AND LISTENERSHIP IN. BULLWINKLE UNDER CONDITIONS OF PURE COMPETITION}

$\begin{array}{clc}\text { Number of Channels } & \text { Formats on Channels } & \begin{array}{c}\text { Total Number } \\ \text { of Listeners }\end{array} \\ \text { 1 (Channel A) } & \text { Top 40 } & 600 \\ \text { 2 (A, B) } & \text { Top 40, Top 40 } & 600 \\ \text { 3 (A, B, C) } & \text { Top 40, Top 40, Classical } & 850 \\ 4 \text { (A, B, C, D) } & \text { Top 40, Top 40, Top 40, } & 850 \\ \text { 5 (A, B, C, D, E) } & \text { Classical } & \\ & \text { Top 40, Top 40, Top 40, } & 1025 \\ & \text { Classical, All News }\end{array}$

These results demonstrate significant format duplication under a system of pure competition. $B$, the second broadcaster to enter the market, will also choose to program Top 40 music, instead of classical music, a nonduplicated sound. This decision logically flows from $B$ 's assumption that he can at least divide the listeners of Group I with broadcaster $A$. By choosing a Top 40 format, $B$ captures both a larger actual audience (300) than he would with a classical format (250) and receives a larger share of the total radio audience ( 300 of 600 , or fifty percent compared to 250 of 850 , or twenty-nine percent). 
The benefits resulting from a larger actual audience and an increased share of the total audience ${ }^{35}$ will encourage duplication and discourage the trial of new formats with each increase in the number of channels. In fact, under a competitive model the smallest group of listeners, which prefers a religious format, will not have its sole choice fulfilled until the number of channels reaches nine. Only then will it be more attractive for an additional broadcaster to claim the 115 listeners in Group IV than to carve another slice of the listening audience of 1025 from the other three formats. ${ }^{36}$ On the basis of similar examples, Steiner concludes that pure competition creates wasteful duplication of already existing formats.

In contrast, a system of monopoly ownership potentially can provide the public with superior programming service by allowing the greatest number of listeners to receive their preferred program format. Because a monopolist would seek to maximize audience size and avoid duplication of competing program services, the available formats would be distributed as follows:

\section{TABLE III. FORMAT CHOICE AND LISTENERSHIP IN BULLWINKLE UNDER MONOPOLY CONDITIONS}

$\begin{array}{clc}\text { Number of Channels } & \text { Formats on Channels } & \text { of Listeners } \\ 1 \text { (Channel A) } & \text { Top 40 } & 600 \\ 2 \text { (A, B) } & \text { Top 40, Classical } & 850 \\ 3 \text { (A, B, C) } & \text { Top 40, Classical, All News } & 1025 \\ 4 \text { (A, B, C, D) } & \text { Top 40, Classical, All News, } 1140 \\ & \text { Religious }\end{array}$

Because the number of channels does not increase boundlessly, Steiner argues that minority audiences are more likely to have pro-

35 These constitute the two critical measures-rating and share, respectivelyof audience rating reports such as the Nielsen Television Index (national survey) and the Nielsen Station Index (market-by-market survey). See, e.g., NIEISEN Television Index, Nersen National TV Ratings, B, C (1978).

${ }^{38}$ At that point, five Top 40 stations (with 120 listeners each), two classical stations (with 125 listeners each) and one all news station (with 175 listeners) will be on the air. This prediction assumes that an existing station will not change its format to increase its audience, i.e., that $A$, the first Top 40 station, with its audience reduced from 600 to 120 , will not switch to an all news or classical format in the hope of forcing an existing classical or all news station to change its format. This assumption is not unreasonable because a format change involves additional fixed costs to $A$, with no assurance that it can succeed against existing stations despite its longevity in the market. Indeed, if it is assumed that listeners are relatively in- 
gramming tastes satisfied under monopoly control than under a system of pure competition.

\section{B. Relationship Between the Steiner Model and the WEFM Case}

Although the WEFM court does not expressly consider or adopt Steiner's economic analysis of radio programming, the decision conforms with Steiner's analysis by rejecting a pure competition approach to format regulation. The court of appeals noted that radio formats should be controlled in a way that maximizes "the diverse interests of all the people of the United States . . . " 37 For monopoly control the court substitutes FCG regulation, because audience size under Steiner's model depends on the number of decision-makers, and centralized regulation can provide the same single-minded coordination as a monopoly. In addition, like Steiner, the court was concerned that certain formats would be duplicated to the exclusion of other programming and that the audience would thereby be deprived of its first-choice programming. ${ }^{38}$ Further, consistent with the Steiner model, the court assumed that increased diversity is necessarily in the public interest. Because of the similarities between the Steiner model and the court's analysis, study of the discernible defects in the assumptions underlying the Steiner model is helpful.

\section{Defects of Steiner's Model and Their Relation to the WEFM Decision}

Despite the relative clarity of Steiner's results, their validity and the theoretical support they lend to the court's decision wane

sensitive to different stations offering the same format, the best that $A$ could achieve would be a three-way split of Group II's listeners, or a two-way split of Group III's listeners, both of which are less attractive in terms of market share and audience size than maintenance of its current format. 1974).

37 Citizens Comm. to Save WEFM v. FCC, 506 F.2d 246, 268 (D.C. Cir.

38 In addition, the court recognized that stations favor audiences most desired by advertisers, such as women between the ages of 18 and 49 , whether or not they constitute a large share of the total audience. Id. Viewed from this perspective, the pure competition model is distorted by advertising demographics and is more at odds with the goal of maximizing listener satisfaction. In terms of the Bullwinkle example, every station might choose to program the all news format if advertisers determined that Group III comprised the only individuals who met their marketing objectives. Thus, total listenership would decline. As the court argued: "If advertisers on the whole prefer to reach an audience of a certain type, e.g., young adults with their larger discretionary incomes, then broadcasters, left entirely to themselves by the FCC, would shape their programming to the tastes of that segment of the public." Id. For a further discussion of this problem, see text accompanying notes 43 \& 44 infra. 
when their underlying assumptions are compared to modern radio practices. First, while Steiner does not explicitly assume that the number of radio broadcasters is small, the disadvantages of the pure competition model are predicated on a small number of stations. Only if the number is small are less preferred formats less likely to be offered under the pure competition model, whereas they will be offered under the monopoly model. This implicit assumption of a small number of broadcasters is erroneous, however, because in many markets the number of competing radio broadcasters is large, not small. More than 8500 radio stations broadcast in the United States, ${ }^{39}$ and large cities have dozens of stations competing for listeners. Indeed, Chicago, WEFM's city of license, had sixtyone radio stations on the air at the time of the proposed transfer. ${ }^{40}$ Although these facts do not in themselves invalidate Steiner's prediction of format duplication, the likelihood that a format preferred by a significant minority of listeners will remain unoffered is substantially reduced in a saturated market. Second, it has not been empirically demonstrated that most listeners have no second choice in programming or that they will decline to listen rather than tune to their second choice of program. Similarly, no statistical proof has been assembled to show that most radio audiences are skewed with a progressively descending distribution of programming tastes. ${ }^{41}$

On the other hand, it is empirically demonstrable that all programs do not have identical costs, as Steiner concedes. ${ }^{42}$ Further, broadcasters may not have maximization of total audience as their sole marketing objective, because, as the WEFM court implicitly recognized, all listeners are not worth equal amounts of advertising revenue to advertisers. ${ }^{43}$ Radio advertising correlates with demographics, and advertisers are most interested in sponsoring programs that attract the likeliest consumers of their product or services. ${ }^{44}$

99 FCC Public Notice, Broadcast Station Totals for May 1978 (June 9, 1978). 40 Citizens Comm. to Save WEFM v. FCC, 506 F.2d 246, 262 (D.C. Cir. 1974).

41 Moreover, audience size is not an especially helpful indicium of programming tastes. Ideally, however, programming tastes should be measured by the intensity of a listener's preference for one format over another and for listening to radio as opposed to engaging in other consumptive activity. See notes 53-57 infra \& accompanying text.

42 Steiner, supra note 33, at 198. 1974).

43 Citizens Comm. to Save WEFM v. FCC, 506 F.2d 246, 268 (D.C. Cir.

14 Virtually every American community has more radio than television stations. Compare Directory of Television Stations in the United States and Canada, BroaDCAsting Y.B., supra note 4, at B-89 with Directory of Radio Stations in the United States and Canada, Broadcastivg Y.B., supra note 4, at G-1. Through radio, adver- 
In addition to these objections to Steiner's premises, his initial assumption that "[ $t]$ here is a meaningful concept of a period of time in which a station presents a single program" 45 is generally inapplicable to modern radio programming. When Steiner developed his model, network programming dominated station schedules, and radio broadcasts were divided into discrete program segments. As a result, Steiner selected the quarter hour as an appropriate unit of measurement. ${ }^{46}$ Although this assumption is applicable to television, which is usually scheduled in multiples of half-hour viewing blocks, contemporary radio is primarily a continuum of entertainment programming without well-defined units. ${ }^{47}$ Today's listeners pick and choose among recorded programming of various stations rather than selecting individual programs. They are more likely, therefore, to move from "sound" to "sound" rather than from "show" to "show." 48 Even when stations organize their

tisers can search out specialized audiences based on the format of a particular station; thus radio attracts advertisers for whom television advertising cannot be cost justified. Audience specialization has had a special impact in rock music advertising that is aimed at a younger generation which reportedly is larger and wealthier than any previous one. Hirsch, supra note 3 , at 275 . One often neglected aspect of radio listening demographics is the underrepresentation of hard-to-survey listeners by the ratings services. See Televiston/Radio Age, Feb. 19, 1973, at 26.

45 Steiner, supra note 33, at 197.

46 Id. Ratings services, such as A.C. Nielsen and Arbitron, provide listener profiles based on an average quarter hour. Some radio stations sell advertising time on the quarter hour interval. See, e.g., Broadcastrng, July 24, 1978, at 48.

47 See Corvallis TV Cable Co., 59 F.C.C.2d 1282, 1285 (1976) (application for assignment of television license granted over objection by nonprofit religious corporation that change would eliminate existing religious programming):

As generally used, the term "format" connotes the full entertainment programming of a particular station and is usually applied to radio broadcast stations rather than to television stations. ... With respect to television stations, it is extremely difficult to categorize the programming presented on such stations under a particular format label, unless all or a majority of the programming is of a specific type.

48 Some stations provide a background, rather than foreground, listening service. In 1955, the FCC began granting FM licenses to stations providing a "functional music" service to stores, factories, and other business subscribers. Broadcastinc Y.B., supra note 4, at A-5. Many stations not licensed in this fashion provide similar service, by classifying their format as "beautiful music" and using pre-packaged instrumental and soft vocal recordings. They are highly rated: a recent Arbitron survey ranked beautiful music stations sixth in New York City, fifth and sixth in Chicago, and fourth in Los Angeles. Broadcastnvg, July 24, 1978, at 48, 49. It is estimated that about 1000 stations in the United States have their day and night service programmed by outside packagers. VARIETY, Sept. 13, 1978, at $49,88$. (Copyright proprietors at one time collected royalties from some business establishments that utilized radio broadcasts as a background music system (as opposêd to nonbroadcast pre-recorded services such as Muzak). The Supreme Court ruled in 1975, however, that businesses were not liable to copyright holders for such use. Aiken v. Twentieth Century Music Corp., 422 U.S. 151 (1975).)

The notice preceding the Format Policy Statement referred to the growth of "sounds" in radio programming and attached as an appendix the philosophy of one 
recorded entertainment around "shows" featuring air personalities, many listeners tune in based solely on the current selection being offered. If the music is unappealing, and another station offers roughly the same format, the listener will tune to the other station, often at the push of a button. ${ }^{49}$ Consequently, Steiner's crucial assumption that listeners tune in preselected discrete programs or do not listen at all is less probable today than it was in 1952.50

Because Steiner's assumptions, particularly those concerning limited channels and second-choice programming, cannot be relied upon, it cannot be determined whether an industry structure based: on pure competition or one based on monopoly (or centralized control, monopoly's functional equivalent) provides greater program. diversity or maximizes listener satisfaction..$^{51}$ The weaknesses of the Steiner model do not a fortiori invalidate the court's approach to the regulation of program formats, for the $W E F M$ court was also concerned with the fact that radio stations tend to select formats favored by particular demographic groups in order to satisfy the preferences of advertisers. Nevertheless, the preceding criticisms of Steiner's model do cast doubt upon the dual assumption that a centralized authority will produce the optimum mix of formats because. it can coordinate format decision-making. Any justification of the court's decision in WEFM must, therefore, rely on evidence of defects in a free-market approach to broadcasting formats.

\section{The Court's Erroneous Correlation of Listener - Satisfaction with Format Diversity}

It is possible that the court did not attempt to rest its analysis solely on an asserted economic superiority of centralized format control. Rather, it may have based its conclusion on the intrinsic

programming director on the importance of this concept. See Changes in the Entertainment Formats of Broadcast Stations (Notice of Inquiry), 57 F.C.C.2d 580, 601-03 (1976) (memo of Terry P. Hourigan, program manager, WMAL-FM, Washington, D.C.). A 1978 survey of developments in radio formating suggests that there may be retreat from specialization, at least among stations that seek to attract the "middle-of-the-road" listener. Broadcastman, July 24, 1978, at 62-68.

40 Radio listening during drive time may represent the most common form of foreground listening today. One notable exception to sound-to-sound listening occurs during promotional contests that require that listeners remain tuned to a particular station for extended periods in order to compete.

50 For an incisive discussion of the effects of Steiner's model on radio format policy, see Owen, Regulating Diversity: The Case of Radio Formats, $21 \mathrm{~J}$. BroaDCAsTINe 305 (1977) [hereinafter cited as Owen (I)]; B. OWEN, THE Economics of Drversity in Broadcasting (Studies in Industry Economics, Dep't of Economics, Stanford University, No. 60, 1976).

51 B. Owen, J. Beebe \& W. Manning, Television Economics 53-55 (1974). See Posner, Monopoly in the Marketplace of Ideas, 86 YALE L.J. 567; 570 (1977). 
value of greater format diversity by reasoning that, centralized control aside, there is a public interest-expressed in terms of first amendment values-in offering listeners greater format choice. ${ }^{63}$ One might find an intuitive appeal to this reasoning, but if this conclusion is to have any economic justification, it must operate so that listener satisfaction is maximized as its consequence. If the public interest corresponds with enabling radio listeners to hear what they desire most, a goal of format diversity is only valid if it helps to maximize listener satisfaction. Otherwise, the court's analysis reduces to an assertion that, in a primarily entertainment context, the public interest should be determined by something other than whether people get to hear what they most want. Under such a rationale, what becomes important is maximizing the number of choices rather than whether doing so yields the most preferred format mix.

An examination of the marketplace demonstrates that the court's intuitive judgment lacks economic foundation. Simply stated, diversity and listener satisfaction are not functions of each other. ${ }^{53}$ If a radio market contains wide program diversity, this means only that it has a larger number of formats than it might otherwise. In contrast, listener satisfaction is not measured by counting formats; it depends on the difference between two variables: (1) the amount that listeners are willing to pay for a particular entertainment format, and (2) the amount that they actually must pay. ${ }^{54}$ This definition follows from the assumption that the less a listener actually must pay for programming for which he is willing to pay some amount, the more satisfied he is as a listener. To determine the amount listeners are willing to pay, the aggregation of each listener's demand, expressed in dollars, for a particular format relative to other available spending choices must be calculated. On the other hand, the second quantity, the price that must actually be paid, is consistently zero (excluding costs of receiver purchase, operation, and maintenance and the opportunity costs associated with listening as opposed to engaging in some other activity) because listeners pay nothing directly for broadcasted sig1974).

62 Citizens Comm. to Save WEFM v. FCC, 506 F.2d 246, 262, 268 (D.C. Cir.

53 See Format Policy Statement, supra note 8, at 863-64. The Commission referred to a study (later published in revised form) by economist Bruce Owen, commissioned by the National Association of Broadcasters, one of over 50 parties filing comments in Docket 20682. Id. 873-74. See also Owen (I), supra note 50.

54 Owen (I), supra note 50, at 311 . 
nals. ${ }^{55}$ The chief consequence of a constant zero price is that it becomes impossible to calculate listener satisfaction. Because listeners know they do not have to pay, no incentive exists for them to determine what they would actually be willing to pay. Measurement of listener satisfaction with a particular format in a world in which broadcast programming is free is therefore utterly speculative. ${ }^{56}$

As an illustration, suppose 100,000 drive-time listeners tune in a "beautiful music" station because they want some unobtrusive background sounds while in traffic, but that they have a relatively weak preference for that programming over another. At the same time, suppose that a group half as large as the first has a strong preference for progressive rock music during drive time. Suppose further that the smaller group could register the intensity of its preference by paying $\$ 2.00$ a year for the programming, while each member of the larger group will pay only $\$ .75$ annually. Under these circumstances, the intensity of the smaller group's demand would exceed the aggregate payments of the larger group. A station able to collect a fee from listeners would choose to satisfy the smaller group's demand, if it could identify that higher paying listenership and if advertising played no part in the decision.

55 See id. 315. In the form of an equation when $P=$ price, $M C=$ marginal cost, and $M R=$ marginal revenue, $P=M C=M R=0$. The aggregate cost of purchasing, maintaining, and operating receivers is reported to amount to a public investment of at least ten times that of the industry in transmission facilities. S. Head, Broadcasting in Ameruca 259-60 (3d ed. 1976). Arguably, listeners reimburse advertisers for their sponsorship of programs when listeners purchase their products and in this sense "pay" for broadcast programming. Advertising costs reIated to many products displayed on television are not inconsiderable. For instance, some patent medicines are described as "a third, a third, a third" products because their budgets consist of three approximately equal parts, one part each for production costs, advertising, and profits. Whiteside, The Man from Iron City, NEw YonkER, Sept. 27, 1969, at 59. On the other hand, mass media advertising expenditures may help to reduce the price of a product in some cases by instantly creating a national sales territory, with the resulting economies of scale in production passed along to consumers. Moreover, of course, a viewer or listener need not buy an advertised product as a condition of watching or listening to a program, even though he must submit to interruptions for advertising. With respect to this issue as it relates to television, however, 84 percent of a recent survey agreed that commercial interruption on television is "a fair price for being able to watch it." Roper Organtzation, Trends in Public atritudes Toward Television and Other Mass Media, 1959-1974 (1975), reported in S. HEAD, supra, at 268.

66 Owen (I), supra note 50, at 316-17. If listeners were required to pay what they bid, they would be reluctant to participate in such a survey, because continued anonymity permits a listener to be a "free rider," listening to entertainment at the expense of another. The "free rider" problem is an old one for entertainment entrepreneurs who depend on "passing the hat" with no assurance that anyone will pay. Publicly-supported television stations encounter precisely this problem when fund raising. 
Realistically, however, commercial broadcasting has no mechanism to measure a demand differential accurately. ${ }^{57}$ Instead, it examines advertisers' desires for a particular type and quantity of listener. If a broadcaster wants to assemble the largest possible audience for an advertiser's message, and if the demographics of the two groups in the hypothetical do not differ significantly, the beautiful music format will be adopted despite the maximized listener satisfaction associated with the other programming. The preceding example shows that programming designed to please the largest number of listeners does not necessarily signal that maximized listener satisfaction has been reached in a market; to be sure, a larger number of people have been satisfied, but less listener satisfaction has been achieved overall.

Similarly, to return to the relationship between diversity and listener satisfaction, it can be demonstrated that the mere number of formats does not necessarily reflect the intensity of listener preferences for each format. Thus, if a choice exists whether to have two Top 40 stations or the more diverse combination of one country and western and one Top 40 station, and if Top 40 listeners would pay more for the option of alternating between two stations with the same format than the two groups of listeners would pay for a system with two different formats, maximized listener satisfaction would correlate with the absence of diversity. Hence, the court's assumption that programming diversity automatically reflects maximized listener satisfaction and, in turn, the public interest, is unavailing.

\section{Problems With Implementing the WeFM Mandate}

In rejecting a marketplace approach, the court of appeals prescribed a procedure for the FCG to follow before approving a license transfer application that would cause the "disappearance of a distinctive format." 58 At the outset, the court instructed the FGC "to determine whether the format to be lost is unique or otherwise serves a specialized audience that would feel its loss." 50 If such a format is involved, the FCC must affirmatively find that the proposed assignment is in the public interest prior to approval. The court indicated that a hearing might be needed at

57 For an expanded treatment of the economic characteristics of alternative market structures, see Spence \& Owen, Television Programming, Monopolistic Competition, and Welfare, 91 Q.J. Econ. 103, 106-22 (1977).

58 Citizens Comm. to Save WEFM v. FCC, 506 F.2d 246, 262 (D.C. Cir. 1974).

59 Id. See also Citizens Comm, to Preserve the "Voice of the Arts in Atlanta on WGKA-AM and FM" v. FCC, 436 F.2d 262, 269, 272 (D.C. Cir. 1970). 
this stage, either to resolve substantial questions of fact or to assist the FCC in defining the public interest. ${ }^{60}$ Finally, the court noted that the mere assertion of past financial losses by the licensee may not be used to justify approval of the transfer application unless those losses are "attributable to the [abandoned] format itself." 61 These operational directives raise several practical problems for the Commission, which are considered below. The FCG addressed some, but not all, of these concerns in its Format Policy Statement.

\section{A. Administrative Problems}

In its Format Policy Statement, the Commission expressed particular displeasure with the court's proposed method of review. The FCC dismissed as unworkable the suggestion that the agency routinely conduct hearings on proposed transfer applications. Characterizing such proceedings as "large-scale litigation which imposes enormous costs on the participants and the Commission alike," 62 the FCC pointed to the thousands of hours of administrative time spent on the WEFM case. ${ }^{63}$ The FCC also noted ${ }^{64}$ that the WEFM decision may also require burdensome hearings in connection with renewal applications because its reasoning arguably applies to all cases of proposed format change. ${ }^{65}$

A final administrative concern raised by the court's mandate is the potential conflict between the indicated hearing procedures

${ }^{60}$ Citizens Comm. to Save WEFM v. FCC, 506 F.2d 246, 262 (D.C. Cir. 1974). 61 Id.

62 Format Policy Statement, supra note 8 , at 864 .

63 [I]n this case, an administrative law judge held two pre-hearing conferences in Washington, D.C.; his preparation time was an additional eight hours. In addition, the Broadcast Bureau trial staff spent above two hundred man-hours of preparation time. Subsequently, hearings were held on nine separate dates in Washington, D.C., and on nine different dates in Chicago, from which a transcript of 3120 pages was compiled. Following the hearings, the Broadcast Bureau spent two hundred and forty hours preparing proposed findings of fact and the administrative law judge will have spent approximately two hundred and eighty hours preparing his initial decision.

Id. 864-65. The reliability of these figures was undermined, however, when the Commission, responding to a Freedom of Information Act request for data and memoranda pertinent to this statement, replied that "there were no written or documented studies as to the amount of time devoted to the WEFM proceedings; rather, the information in the Memorandum Opinion and Order was based on oral estimates given during the hearing by the Administrative Law Judge and participating Broadcast Bureau counsel." Citizens Communications Center, 61 F.C.C.2d 1017, 1018 (1976).

64 Format Policy Statement, supra note 8, at 262.

${ }^{65}$ See, e.g., Cosmopolitan Broadcasting Corp. v. FCC, 581 F.2d 917, 931 (D.C. Cir. 1978) (directing the FCC to apply the WEFM standards in the context of a license renewal). 
and the scope of the Commission's authority to dispose of transfer applications. Under section 310(d) of the Communications Act, the FCG may not consider whether any party other than the proposed transferee is better qualified, ${ }^{66}$ while it may when a license is renewed. ${ }^{67}$ Although a public interest basis for this differential treatment of transfer applicants and renewal applicants does not clearly emerge from the recorded legislative history, ${ }^{68}$ its effect is to preclude consideration of a basic, practical question raised by a transfer involving abandonment of a unique format: does there exist a qualified alternate transferee who can maintain the current format and produce a return sufficient to meet the seller's asking price? The difficulty with inviting such a prospective transferee to come forward arises when a qualified bidder emerges and promises to continue the current format, but offers the seller a reduced price in return for the promise. Open competition at the hearings stage could thus result in allowing the Commission to determine, directly or indirectly, the buyer to which the seller must sell and the price that must be paid. ${ }^{69}$

6647 U.S.C. $\$ 310$ (d) (Supp. V 1975):

Any such application shall be disposed of as if the proposed transferee or assignee were making application under section 308 of this title for the permit or license in question; but in acting thereon the Commission may not consider whether the public interest, convenience, and necessity might be served by the transfer, assignment, or disposal of the permit or license to a person other than the proposed transferee or assignee.

Cf. Minneapolis Star \& Tribune Co., 20 F.C.C.2d 584 (1969) (continuation of control found not to be a transfer within terms of $\$ 310(\mathrm{~d}))$.

6747 U.S.C. $\$ 309$ (a) (Supp. IV 1974).

68 It is difficult to explain the origin of this provision other than as a reflection of broadcasters' efforts to insulate the transfer process-the event at which the accreted capitalized value of a broadcast property is realized-from the competitive forces that come into play with regard to the issuance of other broadcast licenses. Enacted in 1952 as part of a series of amendments to the Communications Act (which had not been substantially revised since 1944), the provision was designed to operate so that "in applying the test of public interest, convenience, and necessity the Commission must do so as though the proposed transferee or assignee were applying for the construction permit or station license and as though no other person were interested in securing such permit or license." H.R. REP. No. 1750, 82d Cong., 2d Sess. 12 (1952). Although the House Committee purported to scrutinize carefully all revisions because of the possibility that several, while largely procedural in nature, "would or might effect basic changes in policy with respect to radio and television broadcasting and related matters," the accompanying House Report provides no clue as to legislative intent behind this section. Id. 2. The amendment foreclosed future efforts by the Commission under its so-called "AVCO rule" announced prospectively in Powel Crosley, Jr., 11 F.C.C. 1, 27 (1946), to permit competing applications in transfer cases. See 2 E. BArNouw, supra note 2, at 292; Wall \& Jacob, Communications Act Amendments 1952-Clarity or Ambiguity, 41 GEORGETOWN L.J. 135, 151-54 (1953).

69 If a buyer were willing to continue the nonduplicated format on the condition that the seller accept a smaller purchase price, the Commission could conceivably assign the license to a buyer to whom the seller did not wish to sell and 


\section{B. Definitional Problems}

The Commission also questioned its ability to classify formats with sufficient particularity to allow it to determine whether a "unique" format is at stake. ${ }^{70}$ While this admission may reflect misplaced modesty-for instance, the FCC has attempted to define "specialty stations" airing "specialty programming" for purposes of the Commission's signal carriage rules for cable television systems ${ }^{71}$-the task of defining formats is not a simple one. ${ }^{72}$ One possible tack would be to rely on the licensee's description of its format in its renewal or transfer application. ${ }^{73}$ This approach settles little, however, because what a station may call "light classics," for example, and what a citizens group or the Commission believes is actually broadcast may be two distinct types of programming. In addition, reliance on these applications gives licensees every incentive to describe their formats as ambiguously as possible. ${ }^{74}$ A licensee could change the constituent parts of its format without admitting to a format change. Conversely, vigorous format regulation by the FCG might discourage broadcasters from selecting an entertainment format that could be viewed as unique

direct the sale at a lower price than the original buyer agreed to pay. Now, the FCC could demand that a buyer promising to retain the format offer as much as the original buyer, but this requirement could conflict with the court's holding that losses allegedly due to the format be shown to arise in fact from that format. See text accompanying note 60 supra. For, supposing that that showing had been made, it would be illogical for the Commission to award the license to a newcomer willing to pay a new format price but who promised to program the same unprofitable format.

The converse is also logically troubling. Suppose that the FCC determines that a licensee's financial losses were not due to its format. Further suppose that the FCC finds that continuation of the format is in the public interest. Under these circumstances, the FCC would be hard pressed to justify a sale to the licensee's designated transferee, whose intent was to eliminate the present format, when a second transferee exists who is willing to continue the present format, merely because the seller would profit less by selling to the second buyer than to the original buyer.

70 Format Policy Statement, supra note 8, at 862-63.

7147 C.F.R. $\$ 76.5(\mathrm{kk})(1977$ ); see Specialty Stations, CATV (First Report \& Order), 58 F.C.C.2d 442, 452-53 (1976).

72 The Commission anticipated its own conclusion about defining formats: "[L]abeling of formats is a subjective matter and similarly labeled ones may in fact differ, while differently labeled ones may in fact substantially overlap." Changes in the Entertainment Formats of Broadcast Stations (Notice of Inquiry), 57 F.C.C.2d 580,583 (1976).

73 See FCC Form 303-R (Application for Renewal of License for Commercial AM or FM Radio Broadcast Station) Question 20, reprinted in [1978] Finding Aids, Master Index, Forms, RAD. REg. 2d (P\&F) 98:303-R-1, R-2 (the applicant must "[d]escribe briefly [its] proposed format"). Question 21 asks whether the applicant's format duplicates that of another station. Id.

74 See Canby, Programming in Response to the Community: The Broadcast Consumer and the First Amendment, 55 Texas L. Rev. 67, 95 (1976). 
and thus immutable in the FCC's opinion. ${ }^{75}$ Hence, unless the FCC orders a station to choose the description of its format from an approved list, a proposition distasteful in first amendment terms because it effectively limits the range of acceptable broadcast expression, a station will remain as tentative and vague as it can in classifying its programming.

The Court of Appeals for the District of Columbia Circuit unfortunately has spread thin ink on the matter. For instance, in 1970 the court made the Delphic pronouncement that, with respect to detecting a distinction between two formats, they would "know it when [we hear] it." "76 Subsequently, the court has differentiated between markedly similar formats: between classical and fine arts in WEFM, ${ }^{7 \tau}$ and between Top 40 and progressive rock in Citizens Committee to Keep Progressive Rock v. FCC. ${ }^{78}$ This type of line-drawing, to be done consistently, could require unprecedented selection-to-selection surveillance by the Commission. In this respect, an attempt to distinguish formats would necessitate much closer scrutiny than the general programming review ordinarily undertaken by the FCC. ${ }^{79}$ Moreover, it would contradict the FCC's espousal of a limited role in other first amendment matters. ${ }^{80}$

75 Id. See also Note, Federal Regulation of Radio Broadcasting-Standards and Procedures for Regulating Format Changes in the Public Interest, 28 Rutcens L. REv. 966, 978 (1975). The station manager of WEFM believes that the WEFM decision has caused other stations to refuse to switch to a classical music format. Telephone Interview with Howard Tanger, Station Manager of WEFM in Chicago (Aug. 3, 1977).

76 Citizens Comm. to Preserve the "Voice of the Arts in Atlanta on WGKA-AM and FM" v. FCC, 436 F.2d 263, 265 n.I (D.C. Cir. 1970) (quoting Jacobellis v. Ohio, 378 U.S. 184, 197 (1964) (Stewart, J., concurring)).

77 Citizens Comm. to Save WEFM v. FCC, 506 F.2d 246, 265 (D. C. Cir. 1974). The court ordered the FCC to conduct a hearing to determine whether the fine arts programming of Chicago station WFMT could substitute for the classical music of WEFM. However, this line-drawing may appear to be more arbitrary than actually was the case because the court recognized that the FCC's definitions of classical music and fine arts music might overlap so much as to render the categories "rough substitutes." Id. At rehearing before the FCC administrative law judge, counsel for WEFM and the transferee sought to show that they were substitutes by means of programming logs and the testimony of the classical music critic for the Washington Post. Telephone interview with Ronald Siegal, counsel for GCC Communications of Chicago, Inc. (Aug. 3, 1977).

78478 F.2d 926, 932 (D.C. Cir. 1973).

${ }^{79} \mathrm{See}$ Georgetown University (WGTB-FM), 66 F.C.C.2d 944, 946 (1977).

80 See, e.g., WGBH Educ. Foundation, [1978] 43 Rad. REg. 2d (P \& F) 1436 (television license renewed over listener group's objection that station broadcast allegedly "offensive, vulgar" programs including Monty Python's Flying Circus and Masterpiece Theater); Oliver R. Grace, 22 F.C.C.2d 667 (1970) (FCC declines to engage in more stringent review of licensee programming on the basis of allegations that "the great majority of broadcast programs are devoted to vulgarity and violence"). See also The Jack Straw Memorial Foundation, 29 F.C.C.2d 334, 354 
The inconclusiveness of industry format nomenclature is another source of difficulty. The listing in Table IV of current broadcast formats and their aliases illustrates the subtle distinctions drawn among the various types of radio programming.

\section{TABLE IV. PRINCIPAL INDUSTRY FORMATS ${ }^{81}$}

Stations are classified under a particular format if a type of programming averages more than twenty hours per week.

1. Agricultural and Farm (in- 17. Greek cluding farm)

18. Hawaiian

2. American Indian

19. Jazz

3. Beautiful Music (including good music and instrumental music)

4. Big Band

5. Black (including rhythm and blues and soul)

6. Bohemian

7. Chinese

20. Middle of the Road (including adult, adult contemporary, bright, up-tempo, good or easy listening, standards, entertainment, and conservative)

21. Navajo and Pueblo

8. Classical (including concert, fine music, semi-classical and serious music)

9. Comedy

10. Contemporary (including popular and request)

11. Country and Western (including country, blue grass, countrypolitan, contemporary country, and modern country)

12. English in Puerto Rico

13. Eskimo

14. Ethnic/Foreign Language

15. Filipino

16. Golden Oldies (including nostalgia, old gold, oldies, solid gold, solid gold rock, and classic gold)

22. All News

23. Polish

24. Polka

25. Progressive (including underground, hard rock, folk, album-oriented rock, alternative, free form, and progressive rock)

26. Public Affairs

27. Religious (including gospel, sacred, Christian, and inspiration)

28. Spanish (not including Puerto Rican)

29. Sports

30. Talk (including discussion, interview, personality, and informational)

31. Top 40 (including contemporary request, rock, popular, and hit parade)

(Review Bd. 1971) (licensee has discretion to air recording Murder at Kent State and to decide whether offensive words are necessary under the circumstances). But see Pacifica Foundation, 56 F.C.C.2d 94 (1975), rev'd, 556 F.2d 9 (D.C. Cir. 1977), $r e v ' d, 98$ S. Ct. 3026 (1978) (Commission may regulate repeated use of indecent words describing sexual and excretory functions).

81 Broadcasting Y.B., supra note 4 , at D-70 to 88 . 
For instance, formats labeled "underground," "hard rock," "folk," "album-oriented rock," "alternative, free form," and "progressive rock" are subsumed under the heading "progressive." Thus, neither the court, the FCG, nor the industry has produced a system of format classification with much operational significance. The court's attempt to finesse the problem by equating a "unique" format with a "format ... [that] otherwise serves a specialized audience that would feel its loss" 82 provides no greater precision. It exchanges one ambiguity (unique format) for another (specialized audience) because a specialized audience is the reflection of a unique format in the audience. ${ }^{83}$ A prime example of the court's mirror image approach is Citizens Committee to Keep Progressive Rock v. FCG. ${ }^{84}$ There, the court of appeals measured the significance of the loss to the public by invoking the colorful standard of "public grumbling." 85 Even for an agency familiar with grumblers in contexts other than format changes, the sufficiency of a particular intervenor's grumble will be hard to determine. Yet, a transfer challenge is at an end if the FCG decides that the grumbling is not sufficiently audible.

The imprecision of format classification also complicates another of the court's WEFM guidelines: the requirement that financial losses cannot be used to justify a format change unless they are attributable to the format. ${ }^{86} \mathrm{~A}$ transferee seeking to change a "unique" format on financial grounds will blame the format for the losses. In response, the intervenors will blame poor management. The FCC will be unable to determine accurately whether the format is the cause of the loss, however, if it cannot differentiate the format under scrutiny from those resembling it. ${ }^{87}$ The inexactitude surrounding the definition of a particular format thereby snarls implementation of the court's directive to discover the source of the loss as well.

82 Citizens Comm. to Save WEFM v. FCC, 506 F.2d 246, 262 (D.C. Cir. 1974).

83 Although the identification of a "specialized" audience would proceed from a survey of the market's audience rather than a comparison of competitors' formats, different groups in the audience would ultimately be connected to their preferred formats. Thus, the court's alternative is a long detour in the same formidable inquiry. Indeed, since it also requires a determination of when the "loss" of the format is "felt," additional vagueness problems emerge. Others, however, have recommended the use of a "specialized audience" test. See Note, Judicial Review of FCC Program Diversity Regulation, 75 Colum. L. Rev. 401, 423-24 (1975).

84478 F.2d 926 (D.C. Cir. 1973).

85 Id. 934.

86 Citizens Comm. to Save WEFM v. FCC, 506 F.2d 246, 262 (D.C. Cir. 1974).

${ }^{87}$ See text accompanying note 83 supra. 
Another deficiency in the court's format definition is its failure to consider substitute sources of recorded radio programming such as records, tapes, and lending services or to differentiate formats that have effective non-broadcast substitutes from those that do not. Most programming that relies on recorded music can be duplicated to some degree by the listener. Other programming, such as all news ${ }^{88}$ or phone-in, is for practical purposes only available on radio. As a result of not adequately distinguishing these different classes of formats, the WEFM court may have overestimated the gravity of the claim of the Committee.

\section{Measurement Problems}

The WEFM court designated the service area, not just the city of license, as the relevant geographical zone for purposes of measuring format diversity. ${ }^{89}$ A transferee is required to show that the current format is duplicated throughout the service area in order to avoid format abandonment hearings. Close examination of the basis of the court's decision reveals its ambiguity. The court relied on its previous decision in Stone $v . F C G,{ }^{90}$ in which it upheld the FCC's dismissal of a license renewal petition that challenged the adequacy of a television station's programming service and minority employment policies. The Stone court used the station's service area ${ }^{91}$ rather than its city of license to evaluate licensee

88 But cf. Stockholders of Rust Communications Group, Inc., 64 F.C.C.2d 883 (1977), in which the Commission granted without hearing a transfer application involving the abandonment of an all news format on WKLX, of Norfolk, Virginia, in favor of a country and western format. The Commission reasoned that the old format was unique

only in the limited sense that WKLXX is the only area station which broadcasts "all news-talk" for sixty minutes each hour. But WKLX is not the only source of radio news in the Portsmouth/Norfolk market . . . . [T]wentyone area stations program news spanning more than forty-five minutes each hour. . . . Radio news is available in the Norfolk area market, therefore, on a twenty-four hour basis, although on different frequencies for over three-fourths of each hour.

Id. 886. The Commission did not explicitly find that the all news format was not unique, but concluded that the public interest would be served by the transfer, particularly in light of the financial losses suffered under the existing format, the loss of an all news network feed, and the program balance proposed by the transferee. Interestingly, the assignment application was opposed not by a citizens group, but by a broadcasting competitor, who happened to be the licensee of one of the four country and western stations that were already serving the Norfolk metropolitan area and who apparently did not want added competition. See note 141 infra \& accompanying text. 1974).

89 Citizens Comm. to Save WEFM v. FCC, 506 F.2d 246, 263 (D.C. Cir.

90466 F.2d 316 (D.C. Cir. 1972).

11 Id. 327. The term "service area" is applicable only to AM radio and not to television or FM radio stations. The court's use of the concept in the television and 
responsiveness to viewer needs and interests. Television, however, differs from standard broadcast (AM) radio in ways critical to format issues. AM radio reception from certain stations with high power output is greatly enhanced at night, which permits the reception of signals from cities 1000 miles away and sometimes farther. This is because AM's signals are transmitted on lower frequency radio waves that can bounce off high atmospheric layers and can be received at greater distances at night when interference caused by solar activity is reduced. ${ }^{92}$ In contrast, FM radio and television signals are transmitted only by higher frequency radio waves, which travel in straight lines relatively unaffected by the atmosphere or solar activity. Television and FM radio stations, therefore, do not increase their service areas at night. ${ }^{93}$

The court seemingly failed to recognize the significance of this difference when it borrowed the concept of service area from Stone. ${ }^{94}$. Although it indicated that the FCG need not be concerned whether a format change will eliminate a unique program service for listeners in distant areas that happen to receive a station's signal, ${ }^{95}$ the court left open the obverse issue: should the FCC consider the impact of a distant AM station that happens to broadcast an otherwise unique programming format into the transferor's service area during desirable hours when it seeks to determine whether the transferor's format is duplicated? ${ }^{96}$ The WEFM opinion does not specify, but it is unrealistic to condemn the loss of a nondupli-

FM radio contexts is thus somewhat inappropriate. Compare 47 C.F.R. $\$ 73.11$ (1977) with id. $\$ 73.311$.

92 See Broadcasting Y.B., supta note 4 , at $A-4$.

is Id. A-4 to 5 .

94 Although the concept was inappropriate in Stone and WEFM, service area does have implications for those AM radio format cases to which WEFM applies.

85 "Areas that receive a distant station under unusual or occasional circumstances or because of fortuitous physical phenomena are not contemplated by this discussion, which relates directly to the problem of metropolitan areas that encompass a major city to which stations are typically licensed." Citizens Comm. to Save WEFM v. FCC, 506 F.2d 246, 263 n,23 (D.C. Cir. 1974). The court would, therefore, deny standing to listeners in those distant areas to challenge a transfer involving a format that is unique to them. It is not clear, however, whether the court was referring to all (or any) of the listeners in a station's "intermittent" service area as defined in 47 C.F.R. $\$ 73.11$ (c) (1977). More generally, in the AM radio context, service area is a broad category that comprises primary, secondary, and intermittent service areas. The court does not explain which of these would apply, perhaps because WEFM was not an AM station.

96 Commercial ratings services often include distant stations in preparing market reports for client stations and advertisers. For example, KGO(AM), a San Francisco station with a news/talk format, is the seventh rated station in Sacramento. The San Francisco station thus lures listeners away from local programming. BroadCASTING, July 24, 1978, at $\mathbf{5 0}$ (citing Arbitron data). 
cated format by day, if programming available from distant stations at sundown serves the critical program needs of the intervenors.97

\section{Summary}

The court's analysis in WEFM does not provide satisfactory guidance for the FCG when it is faced with a petition to deny a license transfer that involves a format change. First, the court's fundamental assumption, that pure competition may not produce as diverse a range of formats as a centrally-controlled regime, stands unsupported by economic theory. Second, its assumption that the public is better off by greater diversity is not necessarily true. Third, its implementing provisions, which require the FCC to determine formats "unique" to the licensee's "service area" and hold complicated hearings, pose serious analytical and practical difficulties for the Commission that the court has not resolved before or in WEFM. In light of these shortcomings, the FCG's prospective rejection of the judicial directive in this area, whatever its eventual legal character, is somewhat understandable.

\section{The FCC's Nonregulation Approach}

\section{A. The Commission's First Amendment Analysis}

The Commission's decision to allow market forces, as reflected in advertising support, to determine a community's format array accords with its previously announced policy to deregulate radio. ${ }^{88}$ Moreover, from a broadcaster's perspective, FCC noninvolvement with format choice is consistent with the first amendment. If the government ordered a publisher to continue to produce an arche-

97 See note 161 infra. The "service area" concept established by the court raises a complicated issue of listener standing under these facts. Assume that the Commission had previously approved a license transfer in market $X$ over listeners' objection based on the availability of an otherwise nonduplicated format from a distant station $Y$. Now, assume that $Y$ seeks to transfer its license and the proposed transferee wishes to alter $Y$ 's format. Assume further that there are no listeners in $Y$ 's service area who wish to oppose the transfer. The court's opinion would seem to deny standing to listeners in market $X$. See note 94 supra. Yet, if the Commission utilizes distant stations to decide whether a format is duplicated, it would seem to have created a right in those market $X$ listeners to complain if they would be deprived of $Y$ 's format.

9837 Fed. Reg. 7946 (1972). See, e.g., Ascertainment of Community Problems by Broadcast Applicants, 53 F.C.C.2d 3 (1975). See also Re-regulation of Radio \& Television Broadcasting, 38 F.C.C.2d 752, 768 (1972) (separate statement of Comm'r Wiley). This concept is incorporated in $\$ 431$ of the proposed Communications Act of 1978, H.R. 13015, 95th Cong., 2d Sess. (1978) (introduced at 124 Conc. Rec. H5128 (June 7, 1978)), which provides that radio station licenses shall be for indefinite time periods (subject only to revocation). 
ology monthly instead of implementing plans to sell its operation to an entertainment tabloid, the constitutional violation would be clear. ${ }^{99}$ Equating its first amendment rights with those of the publisher, the broadcaster undoubtedly finds FCC interference with format decision-making equally offensive.

However, for reasons that go beyond the scope of this Article, including electromagnetic spectrum scarcity, the historical role of federal regulation in broadcasting, and the intrusiveness of the medium in the home, ${ }^{100}$ the electronic press has not been treated as the equal of print journalism. The FCC and the Court of Appeals for the District of Columbia Circuit have generally shown an increasing awareness of this unequal treatment.101 Moreover, the FCC's laissez-faire approach to format regulation reflects dubiety about the scope of the Commission's authority in any matter that involves questions of discretion over content. ${ }^{102}$

The relationship between the first amendment rights of broadcast and print journalists was most recently addressed by the Supreme Court in $C B S$ v. Democratic National Committee, ${ }^{103}$ in which a plurality of the Court rejected the claim that the first amendment and the "public interest" standard required licensees to sell time for editorial advertisements. The court stated that "[f]or better or worse, editing is what editors are for; and editing is selection and choice of material." 104 Equating the first amendment interests of broadcast editors with their print brethren in this context, the Court concluded that "[c]alculated risks of abuse" of editorial power

99 Miami Herald Publishing Co. v. Tornillo, 418 U.S. 241, 258 (1974). See L. Trube, Amerucan Constitutional Law 696-700 (1978); Note, Reconciling Red Lion and Tornillo: A Consistent Theory of Media Regulation, 28 STAN. L. Rev. 563 (1976).

${ }^{100}$ See CBS v. Democratic Nat'1 Comm., 412 U.S. 94, 101-03, 127-28 (1973); Red Lion Broadcasting Co. v. FCC, 395 U.S. 367, 400 (1969); NBC v. United States, 319 U.S. 190, 226 (1943); Pacifica Foundation v. FCC, 556 F.2d 9, 24-30 (D.C. Cir. 1977) (Bazelon, C.J., concurring), rev'd, 98 S. Ct. 3026 (1978); Citizens Comm. to Save WEFM v. FCC, 506 F.2d 246, 274-75 (D. C. Cir. 1974) (Bazelon, C.J., concurring); Bazelon, FCC Regulation of the Telecommunications Press, 1975 Duke L.J. 213, 218-34; Brenner, The Limits of Broadcast Self-Regulation Under the First Amendment, 28 FED. CoM. B.J. 1, 18-41 (1975). See also Canby, supra note 73, at 69-72; Schiro, Diversity in Television's Speech: Balancing Programs in the Eyes of the Viewer, 27 Case W. Res. L. Rev. 336, 340-53 (1976).

101 Indeed, the FCC's Format Policy Statement itself represents a significant effort by the FCC to disengage itself from content-oriented decision-making. Similarly, Chief Judge Bazelon of the District of Columbia Circuit has questioned the continuing validity of the Commission's regulatory mission in the face of the first amendment. See Bazelon, supra note 100.

102 See, e.g., Address by Charles D. Ferris, Chairman, FCC, New England Broadcasting Association, Boston, Mass. (July 21, 1978).

103412 U.S. 94 (1973).

104 Id. 124. 
had to be taken in order to preserve "higher values," the right of editors to be free from governmental dictation as to the exercise of their discretion. 105

But what is the first amendment complexion of format change decision-making undertaken by broadcast licensees? Does it possess the indicia of discretion that attach to a broadcaster's decision how best to cover issues of public importance, such as choice of speaker (e.g., a reporter analyzing the issue as opposed to spokespersons each advocating a side of the issue) or mode of presentation (e.g., a one-hour special as opposed to a series of extended news program segments or a grant of public service announcement time to interested parties)? If so, the $C B S$ analysis would appear to be applicable.

On the other hand, a broadcast licensee's right to choose a programming format may be qualitatively different and may thus constitute a right admitting of, or requiring, greater regulatory oversight than is appropriate to the discretionary considerations just described. Questions of format choice arguably involve matters affecting overall programming, and, as the $C B S$ Court noted in dictum, broadcast licensees can be held accountable for their overall programming without offending the first amendment. ${ }^{106}$ Glearly, format regulation does not amount to administrative scrutiny of day-to-day newsroom editorial judgments. Rather, it calls for a determination at the outset of a transferee's (or, for that matter, a renewal applicant's) license term that the overall service to be provided by a new programming format is in the public interest. On this issue, the Supreme Court in Red Lion Broadcasting Co. $v$. $F C C,{ }^{107}$ its last unified decision in the broadcasting area, in dictum, specifically included a licensee's general program format within the scope of the FCG's oversight powers and observed that "[i]t is the right of the viewers and listeners, not the right of the broadcasters, which is paramount." 108

The free expression interests at issue-those of broadcasters and those of the public they reach-are generally congenial. Ideally,

105 Id. 125. See also NBC v. FCC, 516 F.2d 1101 (D.C. Cir. 1974), vacated, 516 F.2d 1118 (D.C. Cir. 1975), cert. denied, 424 U.S. 910 (1976).

108 CBS v. Democratic Nat'l Comm., 412 U.S. 94, 124 (1973).

107395 U.S. 367 (1969). For a revealing study of the background of this case, see F. Frnendlx, The Good GuYs, the Bad Gưs and the First Adarendment 12-77 (1977).

108 Red Lion Broadcasting Co. v. FCC, 395 U.S. 367, 390 (1969). See National Ass'n of Independent Television Producers \& Distribs. v. FCC, 516 F.2d 526, 536 (2d Cir. 1975) ("The Commission surely cannot do its job, however, without interesting itself in general program format and the kinds of programs broadcast by licensees."). 
the public is best served by free and responsible broadcasters sensitive to the needs and interests of their varying audiences and unfettered by official second-guessing of editorial judgments. ${ }^{109}$ However, when a segment of the public believes that a broadcaster licensed to operate a medium with limited channel capacity is not serving its interests, tension arises between the first amendment rights of the broadcaster involved and the free expression interests of the dissatisfied public segment. ${ }^{110}$ Moreover, because broadcasters are accountable under the "public interest" standard, their critics possess a statutory, if not a constitutional, ground on which to base their claims. ${ }^{111}$

In the entertainment format context, specific judicial pronouncement has not yet been made on the appropriate balance of the competing first amendment claims of broadcasters and citizen groups. Although it is desirable to preserve the principle of public accountability of broadcasters' judgments suggested by the Red Lion Court, one is reluctant to extend accountability to a point at which editing is no longer "what editors are for," but has evolved into the satrapy of government regulators. There may arise, however, circumstances in which the free expression rights of the audience, including those "specialized" audiences that "feel" the loss of a nonduplicated format, must predominate over a licensee's acknowledged constitutional interest in freedom from regulation of its programming content. Under such circumstances, a surrender of the Commission's authority over formats in the name of broadcasters' rights seems contrary to the first amendment hierarchy set forth in the dictum from Red Lion quoted above ${ }^{112}$ and codified in the "public interest" standard of the Communications Act of 1934. The FCC seemingly recognized this hierarchy of rights in its Format.

109 This point of view is analogous to the so-called "libertarian" theory of the press. See Siebert, The Libertarian Theory of the Press, in F. SIEbert, T. PEternon, and W. Schramm, Four Theories of the Press 39, 51-53 (1956).

110 This facet of broadcasting correlates with the so-called "social responsibility" theory of the press. See Peterson, The Social Responsibility Theory of the Press, in F. Siebert, T. Peterson, AND W. SchramM, supra note 107, at 74 . See generally W. Hocking, Freedom of the Press (1947).

111 The statutory foothold of "public interest" would disappear under the proposed Communications Act of 1978, H.R. 13015, 95th Cong., 2d Sess. (1978) (introduced at 124 CoNG. REc. H5128 (June 7, 1978)), a point not lost on its critics during the related hearings. A Bill to Replace the Communications Act of 1934 with the "Communications Act of 1978": Hearings on H.R. 13015 Before the Subcomm. on Communications of the House Comm. on Interstate \& Foreign Commerce, 95th Cong., $2 d$ Sess. (1978), reported in Broadcasting, Aug. 28, 1978, at 30 . Section 437 of the proposed legislation, however, would preserve a procedure for petitions to deny licenses to television stations.

112 See note 107 supra \& accompanying text. 
Policy Statement, by identifying its first amendment objective as the promotion of "the greatest diversity of listening choices for the public." 113 Despite this espousal of the audience's first amendment rights in principle, the practical effect of the Commission's approach is to subordinate the listener's interest to the first amendment rights of the broadcaster. ${ }^{114}$

\section{B. The Commission's Economic Analysis}

Just as the court's economic analysis broke down when its assumptions were examined in light of contemporary industry structure, ${ }^{115}$ the FCC's analysis also lacks a reliable economic foundation. It cannot be shown by economic theory that a marketplace approach will maximize listener satisfaction. The FCC does not assert that maximization of format variety correlates with listener satisfaction. The Commission did choose, however, to rely on market forces to determine format variety,"10 despite its admission that the "market for radio advertisers is not a completely faithful mirror of the listening preferences of the public at large." 117 This conclusion is vulnerable as a matter of logic, because the Commission failed to explain the correlation between nonregulation and maximum listener satisfaction. More basically, the FCC's conclusion relies on an unmeasurable quantity: listener satisfaction. Whatever the theo-

113 Format Policy Statement, supra note 8 , at 863 . By totally withdrawing its regulatory supervision of license transfers that involve changes in formats, the Commission seems to have rejected consideration of a more moderate position that would allow some regulation, albeit less than the court would appear to recommend. Part V of this Article offers such an approach.

It has been suggested that the correct first amendment approach balances the free press rights of the broadcaster against the need for governmental intervention (the "press model"), not the broadcaster's rights against the public's right to receive a diversity of expression (the "speech model"). Note, Press Protections for Broadcasters: The Radio Format Change Cases Revisited, 52 N.Y.U. L. REv. 324, 327, 340 (1977). The need for Commission intervention in the radio format area virtually always arises, however, as a means of advancing listeners' rights to receive. Contrary to the assertion that the speech model "creates an artificial contest between broadcasters and listeners, both of whom properly belong on the same side of the fence," id. 340, broadcasters often have objectives that differ from those of their audience. See text accompanying notes 109-11 supra. Therefore, the proper role of the FCC is to enforce the rights of the audience, assuming adequate justification for intervention into the broadcaster's activity has been shown. The two suggested models therefore do not operate independently in this context.

114 "As Chairman Wiley has observed, "[e]ven after all relevant facts have been fully explored in an evidentiary hearing, we would have no assurance that a decision finally reached by our agency would contribute more to listener satisfaction than the result favored by station management.' 57 F.C.C.2d 580, 586 (1976)." Format Policy Statement, supra note 8 , at 865.

115 See notes 37-57 supra \& accompanying text.

116 Format Policy Statement, supra note 8, at 863.

117 Id. 
retical value of this elusive concept as a measure of the public interest, it is incapable of practical application.118 Because one can only determine audience size (a figure itself subject to the infrequency and imprecision of private ratings services) and not the price that listeners would pay for the programs that they receive for free, one cannot measure listener satisfaction in the marketplace. A fortiori, it should not be relied upon as the touchstone for determining the public interest. ${ }^{119}$

By deferring to market forces, the Commission wrongly supposes that advertisers' time-buying decisions sufficiently reflect the program choices of listeners. In fact, the criterion that advertisers ordinarily consider in deciding to sponsor a program-the probable correlation between sponsorship and sales of their products-does not necessarily bear a relation to the intensity of a listener's desire to hear the sponsored program. A young adult, valued by advertisers for his higher than average discretionary income, may be more likely than others to buy an advertiser's product, but that spending motivation does not necessarily reveal anything about the intensity of his interest in the program that the advertiser sponsors. Contrarily, an elderly person with a smaller discretionary income than the demographically attractive young adult might be willing to pay more for a classical music format than the young adult would for a Top 40 format. Yet, because the younger consumer is more likely to buy the advertiser's product, his program preference, however slight, is satisfied ahead of another who would spend his discretionary income for radio programming, but not on the advertiser's product.

If radio generally were financed through subscription sales, listeners' demand could be used to determine format choice. Also, it would be more likely that listeners' satisfaction could be monitored by the standard now used by advertisers-audience size: the greater the desire for a particular format, the greater the number of

118 The Commission never formally equates listener satisfaction with the public interest, but at least twice it refers to maximization of the welfare of listeners as a controlling guideline. See id. 861, 865. At another point, the Commission discusses the importance of regulatory flexibility in order to adjust to changing listener tastes. Id. 864. Furthermore, it articulates no guideline other than listener satisfaction for determining the public interest in the format context and specifically rejects enhanced diversity as an appropriate measure. Id.

119 See notes 53-56 supra \& accompanying text. Cf. Cowles Fla. Broadcasting, Inc., 60 F.C.C.2d 372, 445 (1976) (Robinson, Comm'r, dissenting) (footnotes omitted), clarified, 62 F.C.C.2d 953 (1977), vacated and remanded sub nom. Central Fla. Enterprises, Inc. v. FCC, No. 76-1742 (D.C. Cir. Sept. 25, 1978):

An auction [as a system of allocating licenses] combines the simplicity of the lottery with two additional virtues: one, it would allow the public to recoup the economic value of the benefits conferred upon private licensees; two, unlike a lottery an auction measures the intensity of individual prefer- 
listeners who would pay for it. ${ }^{120}$ If it is assumed that production expenses and the price charged listeners are about the same for all formats and that the cost-free availability of the format would not deter too many listeners from subscribing (assumptions that are in the first instance hard to test and in the second somewhat improbable), the FCG could leave the regulation of format changes to market forces. In the absence of a subscription scheme, however, it is impossible for the Commission to rely on marketplace spending choices to evaluate the public interest in a format change case. Thus, the FCC's identification of maximum listener satisfaction with the public interest, although theoretically the correct first step, is meaningless in a system of competitive, advertiser-supported broadcasting.

\section{Summary}

This analysis demonstrates that there is no valid economic model with which to identify the public interest in format disputes. The court of appeals' lack of a reliable economic justification for its result is mirrored in Steiner's flawed model: both erroneously contend that centralized market control is preferable to a competitive structure. Moreover, the court's identification of increased format diversity as an independent public interest objective is based on the false premise that greater diversity necessarily enhances listener satisfaction.

ences, in accordance with the prevalent standard for allocating resources

in our economic system.

Commissioner Robinson seems to assume that auction participants would be listeners who would bid according to their preferences. It would be more reasonable, however, to assume that the participants would be communication entrepreneurs, who would bid not according to their own listening preferences, but according to their estimate of the economic value of the license. In any case, the Commission as a whole has not pursued the idea of switching to an auction system, as suggested by Commissioner Robinson and others. See Jones, Use and Regulation of the Radio Spectrum: Report on a Conference, 1968 WASH. U.L.Q. 71, 81-97; Note, Concepts of the Broadcast Media Under the First Amendment: A Regulation and a Proposal, 47 N.Y.U. L. REv. 83, 106 (1972).

120 Although small in number, subscriber supported stations have been the source of some of radio's most controversial programming. The best known of these stations are those operated by the Pacifica Foundation: WPFW-FM, Washington; KPFX-FM, Los Angeles; KPFA-FM and KPFB-FM, Berkeley; and WBAI-FM, New York. See Pacifica Foundation, 36 F.C.C. 147 (1964). See also Pacifica Foundation, 56 F.C.C.2d 94 (1975), rev'd, 556 F.2d 9 (D.C. Cir. 1977), rev'd, 98 S. Ct. 3026 (1978). Subscription television without a pay-for-play foundation is not unknown: KVST-TV, a Los Angeles UHF station, operated for nearly two years on a noncommercial basis with viewer donations. The station eventually went dark for lack of funds. Stations affiliated with the Public Broadcasting Service also operate in part through subscribers' donations, and "true" pay-per-program service is currently offered in three American markets. (A device that unscrambles the transmitted signals is attached to the home receiver.) Broadcasting, Aug. 28, 1978, at 85 . 
The FCC's physiocratic solution is unsatisfactory as well. Although the Commission avoids the error of concluding that the public interest, as measured by listener satisfaction, is best served by increased diversity, it does assume that listener satisfaction is quantifiable. It then concludes that market forces, rather than agency adjudication, will result in a higher degree of satisfaction. With an advertiser-supported broadcasting industry, however, listeners cannot express their demand for programming through spending choices as they do for other goods and services in the marketplace. The Commission's central assumption is invalid, and its solution is therefore illusory.

Despite its estrangement from factual reality, the FCC's nonregulation approach might be acceptable if no other plan commended itself, because the absence of regulation should be at least as attractive to policy makers as affirmative regulation based on faulty premises..$^{121}$ What follows is a proposal that seeks to avoid the pitfalls of the court's course of misfeasance as well as the Commission's declaration of nonfeasance in resolving format disputes. It assumes that principled government regulation can achieve a more satisfactory result than a free market solution. In light of the first amendment's hostility toward such regulation, however, it tries to limit the number of content-related decisions that the governmental agency must render.

\section{A Proposal for Encouraging Voluntary Settlement of Ghallenges to Format Changes}

To develop a new approach to the format problem, it will be useful to review the concepts of merit goods, subformats, and the dynamics of citizen group challenges.

\section{A. The Relevance of the Concept of Merit Goods to the Format Problem}

It is instructive to consider the perspective of one member of the Commission in the aftermath of WEFM:

To permit a situation in which, hypothetically, every station in a given locale could program identically so as to optimize audience size-whether the preferred program-

121 This is Professor Owen's conclusion. See Owen(I), supra note 50, at 317; cf. Home Box Office, Inc. v. FCC, 567 F.2d 9 (D.C. Cir.), cert. denied, 98 S. Ct. 111 (1977) (FCC rules against the siphoning of programs by cablecasters was held invalid as beyond the scope of demonstrated FCC authority). 
ming be all-classical, middle-of-the-road, two-way talk, etc.-would be to countenance the same kind of improper exclusion that minorities suffered during the earlier days of the media, of which unfortunate vestiges remain today. ${ }^{122}$

Implicit in this statement is the assumption that even in a system in which the intensity of listener preferences could be measured and translated into programming decisions, there are interests unsatisfied by marketplace forces that would deserve attention under a public interest analysis. Some formats should not be allowed to be priced off the air, according to this reasoning, for the same reason that commercial exploitation of national parkland is prohibited even though the revenues lost might outweigh discernible economic benefits.

These protected formats are a form of merit goods, that is, goods that are believed to make the communities in which they are generated better places in which to live, and goods that should be preserved even if they represent economically inefficient uses of their constituent resources. In the broadcasting context, merit goods can be defined as programs that would not be aired if broadcasters depended on their ability to attract advertising dollars as the sole indicator for determining whether to retain the program. For example, a weekly black public affairs program on an urban station, if it could be evaluated in terms of listener satisfaction, might generate a less intense demand than would purely entertainment programming. Yet, because this type of program is considered to contribute more to a community's well-being than a program of recorded music, it is not replaced regardless of the contingency of the benefit or the limited number of beneficiaries. ${ }^{123}$

122 Changes in the Entertainment Formats of Broadcast Stations (Notice of Inquiry), 57 F.C.C.2d 580, 588 (1976) (Hooks, Comm'r, concurring) (quoting WQFM-FM, 40 F.C.C.2d 534, 535 (1973) (Hooks, Comm'r, dissenting)). Commissioner Hooks renewed his objection to the Commission's approach in dissenting to the Format Policy Statement, supra note 8, at 882 (dissenting opinion): "I do dissent because, without suggesting an alternative response to minority format abandonment, the majority does not provide a mechanism to ensure service to signifcant minority tastes and needs if market forces do not."

123 Cf. National Ass'n of Independent Television Producers \& Distribs. v. FCC, 516 F.2d 526, 537 (2d Cir. 1975) (footnote \& citation omitted):

While motion pictures are protected against censorship under the First Amendment, . . . it would be folly not to recognize that their protection, except for censorship of content, is not as strong as is the protection in broadcasting invoked by the discussion of public issues. The public interest, in the general regulation of broadcasting, may require some sacrifice of an entertainment category for a public affairs category on a non-discriminatory basis. 
News and public affairs programs often operate as merit goods. Indeed, a portion of the profits generated by entertainment programming is used to pay for some news and public affairs programs that, under strict marketplace conditions, are not cost-justifiable. The presence of such "sustaining," or public service, programming on the air can be explained only if considerations other than economic profitability sometimes predominate. ${ }^{124}$ For the purposes of this Article, the merit goods concept can be applied to a format rather than a specific program.

Yet, the protection of some formats, and all public service programming for that matter, as merit goods would contravene the first amendment and section 326 of the Communications Act, ${ }^{125}$ which forbid government censorship, by according a preference to certain types of expression. This approach assumes that programming should be judged by what the government thinks ought to be heard, instead of by what people desire to hear. Although public affairs programs might survive in a free market system in which program formats reflected the number of listeners with particular preference intensities, it is unlikely.

Another problem is the difficulty of determining what constitutes merit goods. In this regard, a key passage from the Red Lion decision is applicable: "It is the right of the public to receive suitable access to social, political, esthetic, moral, and other ideas and experiences which is crucial here. That right may not constitutionally be abridged either by Congress or by the FCC." 128 Taking "esthetic" in its most expansive sense, virtually all entertainment shows, including the very ones displaced by public affairs programming, might qualify as merit goods. ${ }^{127}$ Indeed, the Committee

124 See federax Communications Comm'n, Public Service Responsibintty of Broadcast Licensees (1946), reprinted in Documents of American BroadcastING 15l, 174-75 (2d ed. 1972).

12547 U.S.C. $\$ 326$ (1970). This section of the Communications Act of 1934, incorporated without change from $\$ 29$ of the predecessor Radio Act of 1927, Radio Act of 1927, Pub. L. No. 69-632, $\$ 29,44$ Stat. 1162 (1927), expressly provides that "the right of free speech by means of radio communication" is not to be sacrificed to the need for regulation. The Supreme Court has seemingly reduced this provision to something of a legislative gelding by limiting its application to a mere bar on prior restraints. See Pacifica Foundation v. FCC, 98 S. Ct. 3026, 3033-35 (1978).

126 Red Lion Broadcasting Co. v. FCC, 395 U.S. 367, 390 (1969) (emphasis added). See Winters v. New York, 333 U.S. 507 (1948); Hannegan v. Esquire, Inc., 327 U.S. 146, 158 (1946); Capital Broadcasting Co. v. Mitchell, 333 F. Supp. 582, 591 n.25 (D.D.C. 1971) (Wright, J., dissenting), affd sub nom., Capital Broadcasting Co. v. Acting Attorney General, 405 U.S. 1000 (1972). See also T. EMrerson, Toward A General Theory of the First AMendrent 59 (1966); A. Meikrejohn, Free Speech and its Relation to Self-Government 91 (1948).

127 First amendment protection of entertainment expression applies not only to serious-minded advocacy of controversial ideas but also to seemingly foolish por- 
organized to save the classical music provided by WEFM could argue that that format deserves merit goods status. Under these circumstances, the more carefully the FCC tries to separate more meritorious from less meritorious programs, the more it impales itself on the blue pencil of censorship.

Although these complications counsel a rejection of a merit goods approach here, they reflect a fact of broadcasting life in the United States, either because a program director believes that such programs will attract an audience despite the cool reception from advertisers (who often are principally interested in the program's projected audience, not in the program itself), ${ }^{128}$ or because the FCG has indicated that they constitute part of a licensee's public service duties. Hence, in formulating a meaningful format policy, it is useful to examine in greater detail why some programming should not be subject to purely competitive bidding by listeners or advertisers.

Consider this hypothetical fact situation. Following a Christmas Eve earthquake, officials determine that a warning to homeowners in a remote town to disconnect gas mains could avoid $\$ 250,000$ in aggregate property damage. The only practical way to disseminate this warning is by transistor radio. However, a religious music fanatic is willing to pay $\$ 275,000$ to all radio stations in the quake area in order to enjoy twenty-four hours of uninterrupted holiday music. If a preference intensity approach to program purchasing is assumed, the value of uninterrupted musical programming exceeds the value to property owners of that air time. In terms of economic efficiency, the sole bidder should not be denied his uninterrupted programming. Yet the compulsion to program inefficiently is strong.

The distaste here for economic efficiency derives from two sources. First, there is the private economic loss felt by each prop-

trayals. Joseph Burstyn, Inc. v. Wilson, 343 U.S. 495, 501 (1952); See Winters v. New York, 333 U.S. 507, 510 (1948) ("The line between the informing and the entertaining is too elusive for the protection of that basic right [of a free press]."); Citizens Comm. to Save WEFM v. FCC, 506 F.2d 246, 271 n.9 (D.C. Cir. 1974) (Bazelon, C.J., concurring). But cf. Powe, "Or of the [Broadcast] Press," 55 Texas L. Rev. 39, 63 (1976) ("At bottom, television is regulated because its entertainment-oriented forum does not seem to merit protection as part of the exposition of ideas, because the medium is innately sensed as too powerful, and because the status quo seems to offer security.").

128 For instance, Roots, a TV series that reportedly attracted viewers in 36,380,000 households, the largest viewing audience in television history, for its final episode, see VARmETr, May 10, 1978, at 174, was offered to advertisers at rates far below what its ratings later justified. See Broadcasing, Feb. 7, 1977, at 52, 56. For a discussion of merit goods, see Spence \& Owen, supra note 57, at 122 (discussing the market's bias toward programs that "ought" to be produced). 
erty owner who suffers avoidable loss because a single listener has satisfied his desires. Second, and more significant than the disappointment of property owners, there is the loss felt by the community because a resource that should be marshalled to serve a broad public purpose is squandered to satisfy the musical appetite of an individual listener. The determination of merit goods status for a one-time emergency broadcast does not, of course, validate a merit goods categorization for any particular format. Yet the resulting community disappointment provides by consensus a reasonable ground for applying a merit goods approach.

Reliance on market forces for format allocation is preferable, but it cannot be justified in all circumstances. At some point between a marketplace approach and complete governmental program coordination a balance must be struck in order to preserve community resource control through limited government intervention. In the broadcasting context, the articulated first amendment preference for listeners' rights over the business objectives of the broadcaster in cases of conflict provides a constitutional basis for overcoming an otherwise heavy reluctance to regulate what is transmitted over the air. ${ }^{129}$ The first amendment suggests that the FCC should refrain from merit goods judgments if it can possibly avoid them. Nonetheless, when the Commission is apprised of facts leading to the conclusion that it would be better to regulate affirmatively than to stand aside, it should do so..$^{130}$

\section{B. Subformats}

Many stations do not program only one format but, as Table $\mathrm{V}$ indicates, use two or more subformats. Some subformats are heard only one or two hours weekly while others alternate with the regu-

120 Cf. Cosmopolitan Broadcasting Corp. v. FCC, 581 F.2d 917, 931 (D.C. Cir. 1978) ("Meritorious programming, after all, is that programming which serves the public interest, convenience and necessity."); A Bill to Replace the Communications Act of 1934 with the "Communications Act of 1978": Hearings on H.R. 13015 Before the Subcomm. on Communications of the House Comm. on Interstate \& Foreign Commerce, 95th Cong., 2d Sess. (July 18, 1978), reprinted as FCC Mimeo No. 3130, at 7 (Statement of FCC Chairman Ferris) ("My purpose is to underscore the point that regulatory intervention of some type is still very necessary when markets do not work properly.").

130 [1977] Broadcasting Y.B. D-84 to 96 . The 1978 Broadcasting Yearbook, presenting an abridged summary of subformats, lists many of the subformats contained in the 1977 summary under the individual station descriptions only, rather than in the tables of formats, 


\section{TABLE V. SPECIALTY FORMATS 131}

The following subformats are heard on radio stations for less than twenty hours per week. In addition, some of the formats in Table IV are also heard less than twenty hours per week. Some but not all of these formats appear on commercial stations.

1. African

2. Albanian

3. Aleut

4. Arabic

5. Armenian

6. Asian

7. Basque

8. British

9. Calypso

10. Carribean

11. Children

12. Chinese

13. Czech

14. Dutch

15. East Indian
16. Educational

17. Finnish

18. German

19. Haitian

20. Hebrew

21. Hindu

22. Hungarian

23. Indo-Chinese

24. Irish

25. Korean

26. Lithuanian

27. Norwegian

28. Persian

29. Portuguese

30. Punjabi
31. Romanian

32. Russian

33. Scandinavian

34. Serbian

35. Slovak

36. Slovenian

37. Swedish

38. Swiss

39. Tibetan

40. Ukrainian

41. Variety

42. West Indian

43. Women

44. Yugoslavian

45. Yupik

lar format throughout the day. ${ }^{132}$ The court, the Commission, licensees, and intervenors have not, in the past, considered the commercial viability of subformats in resolving format challenges. This viability suggests that broadcasters, citizen groups, and the FGC need not view every format change as an absolute proposition. Instead, in appropriate situations, a subformat orientation that apportions broadcast time among the competing formats could provide a reasonable way to accommodate the intervenors' complaint. ${ }^{133}$

131 See National Ass'n of Independent Television Producers \& Distribs. v. FCC, 516 F.2d 526, 542 (2d Cir. 1975): "The development of competition, while desirable, is not the single goal for the Commission, as it may be for the Department of Justice."

132 A "subformat" arrangement is distinct from a "sharing time" arrangement in which two licensees divide the broadcast day. See 47 C.F.R. \$73.74 (1977).

133 Reliance on subformats has limitations, however. Some stations provide that the specialty formats detailed in Table $V$ replace regular programming that goes unsponsored, usually on weekends and late at night. Packagers pay these stations a flat fee to broadcast taped specialty programs. The cost is recouped by the packager either from advertising spots in the program or from contributions solicited during the programs. Such arrangements may pose problems for licensees when they amount to a wholesale delegation of authority to the packager or involve programs that are produced in a foreign language. Both problems emerged in Cosmopolitan Broadcasting Corp. v. FCC, 581 F.2d 917 (D.C. Cir. 1978). 


\section{Dynamics of Citizen Petitions to Deny}

While there are many facets to citizen efforts aimed at convincing the FCC to deny an application for broadcast authority, one observation predominates: a successful petition effort is unlikely. ${ }^{134}$ Rather, a petition to deny, most commonly filed to challenge license renewal applications, ${ }^{135}$ operates as a Damoclean sword to induce licensees to negotiate over citizen grievances in good faith and thereby avoid costly, if not very risky, legal battles. Negotiations between station and petitioner conducted in the shadow of a petition to deny can produce a clear perception of citizen grievances and the broadcaster's response to them. It is on the heightened clarity arising out of the negotiating process that the following proposal focuses.

\section{A Proposed Regulatory Solution}

This Article advocates a regulatory scheme that integrates the viability of subformats, the dynamics of station-citizen negotiations, and the fact that some formats may deserve merit goods status into a procedure that would encourage the parties in a large proportion of format challenges to agree to divide the station's programming between the current and the proposed format in an effort to settle their dispute inexpensively. The amount of time allocated to each subformat would be determined through negotiations that identify the most sought-after hours for the current format and leave the remainder for the new format. However, if the parties cannot agree on the extent to which each subformat should be aired, the merit goods concept is summoned, and the FCG will determine whether the current format should be maintained. Significantly, non-content-related incentives are incorporated in the proposed regulation to avoid negotiation stalemate, or alternatively, an ultimate agency decision on the format issue.

The proposal, in the form of an FCC regulation, would be added to the Code of Federal Regulations as parts 73.127 and 73.302 of Title 47 . It would provide as follows:

(1) In the event of a proposed change of format that is nonduplicated throughout the station's [secondary service area

134 See generally J. Grundfest, Citizen Participation in Broadcast LicensING BEFore THE FCC, (Rand Corporation R-1896-MF 1976); Schneyer, An Overview of Public Interest Law Activity in the Communications Field, 1977 Wis. I. Rev. $619,623$.

${ }^{135}$ See 47 U.S.C. $\S \S 307(d), 309(d)$ (1970). 
(AM) $]^{136}$ [larger field strength contour (FM) ${ }^{137}$ which is submitted in connection with any application to which section 309(d) of the Communications Act applies, ${ }^{138}$ the FCG will proceed to dispose of the proposal as follows:

(A) if there is no objection to the format change filed pursuant to section $309(\mathrm{~d})(1)$, the Commission will approve the format change request without a hearing.

(B) if a party in interest files a petition pursuant to section $309(d)(1)$ objecting to the proposed format change and the proposed change involves loss of more than sixty percent of the average number of hours of the nonduplicated format broadcast by the licensee, then

(i) if within three months of the date of filing the petition, the licensee and the party in interest reach agreement providing for partial retention of the existing format in exchange for withdrawing the petition, and the agreement is in conformity with FCC regulations regarding citizen settlements, the Commission will approve the agreement and grant the application for transfer under section $310(\mathrm{~d})$;

(ii) if within three months from the date of filing the petition no agreement has been submitted to the Commission, the Commission will conduct a hearing pursuant to section 309 (e) to determine whether the proposed change is in the public interest, provided that the party in interest submits to the Commission a statement signed by one percent of the population of the city of license that shall state that the signers object to loss of the program format currently provided by the licensee.

(a) Each signer shall add to his signature his place of residence giving street and number. If no street and

136 This concept, defined at 47 C.F.R. $\$ 73.11$ (b) (1977), provides a more specific administrative focus than the generic "area of service" concept, although it does not designate with precision the relevant geographical boundaries. For the reasons suggested earlier, there can be no exact line drawing for standard broadcast (AM) signals. See notes $92-97$ supra \& accompanying text.

137 See 47 C.F.R. $\$ 73.311$ (1977). This region would include areas receiving a field intensity of 60 decibels above one microvolt per meter from the station's signal. This unit of measurement is applied in the cross-ownership context. See id. $\S \S 73.311(b)(2), 73.240$.

138 Although the WEFM case and its predecessors involve format changes accompanying an application for license transfer, there would seem to be no reason why the public interest inquiry made by the Commission with respect to a transfer application would not be pertinent to an application for renewal of license. Thus, the proposed regulation would apply both to the transfer and renewal situations. See note 65 supra \& accompanying text. 
number exist, then a designation of the place of residence shall be given which will enable the location to be readily ascertained.

(b) Each statement shall be submitted with an affidavit made by a resident of the city of license. The affidavit shall state that the affiant circulated the statement and saw written the signatures appended to it and that according to the best information and belief of the affiant each is the genuine signature of the person whose name it purports to be and the signer is a resident of the station's city of license.

(c) The station shall have the right to challenge the authenticity of the signatures.

(d) For two months prior to the end of the threemonth period the station will broadcast once a day (l) the fact that it has petitioned for a format change and (2) the name, address, and telephone number of any party that has filed a petition objecting to the change, with a brief statement indicating the purpose of that party's objection and where one may go to sign the objectors' statement.

(e) Any petition to deny submitted for purposes other than those relating to the retention of a nonduplicated format shall not be governed by this section.

(2) The burden of pleading and proof that a format is nonduplicated in the relevant area shall be borne by the petitioning party in interest. ${ }^{139}$

(3) Any applicant whose proposed format change is approved subject to an agreement described in subpart (1)(B)(i) of this section shall be entitled during the following licensing term to:

(A) a prima facie presumption that its broadcasting operation is substantially responsive to the needs, views, and interests of its service area;

(B) a waiver from Commission oversight of the station's ascertainment processes (the Commission may in its discretion extend in duration the waiver described in this section at the time of approving the settlement);

139 Although this provision does not eliminate the ambiguity surrounding a format's uniqueness, it does remove the licensee's present burden of demonstrating that its format is not unique and thereby eliminates some drawbacks of experimenting with unduplicated formats. See note 75 suvra \& accompanying text. 
(C) if applicable, a waiver from the $50 \%$ non-duplication rules of 47 C.F.R. $\$ 73.242$ relating to simultaneous AM/FM transmission;

(D) a _ \% discount in all fees charged by the Commission in connection with the administration of the license.

(4) No reimbursement may be paid by a licensee to any party in interest for costs, including reimbursements for legal expenses or solicitation of signers, incurred by that party prior to hearing. ${ }^{140}$

(5) In approving any settlement the Commission must find that all parties to the agreement engaged in arms-length, good faith negotiations.

\section{E. The Model Upon Which the Proposal is Based}

A basic premise of this proposal is that to function effectively a settlement-oriented scheme must offer a net incentive to the transfer applicant and current licensee. Because settlement constitutes partial defeat, a licensee or transferee burdened by enforced continuation of a format can fairly question why it should be required to endure lower profits, while other stations already airing the proposed format are not similarly burdened. ${ }^{141}$ The following analysis indicates that with the incentives enumerated in subpart (3) of the proposed regulation, a broadcaster can make a rough cost/benefit analysis of resisting the citizen group's objections ${ }^{142}$ and thereby determine whether a net incentive to settle exists.

140 This prophylactic provision discourages nuisance challenges to proposed format changes. It resembles the limitations placed on class action settlements whereby named plaintiffs who are often the attorneys initiating the lawsuit are required to give notice of settlement to the class. See FED. R. Crv. P. 23. It may be desirable to require that the licensee offer to the party in interest a right of first refusal to the license, on the same terms and conditions as offered to the transferee. This suggestion, however, appears contrary to 47 U.S.C. $\$ 310$ (d) (Supp. V 1975), which limits the Commission's inquiry concerning proposed transferees to the designated applicant only. See note 68 supra \& accompanying text. Although the relative simplicity of deciding transfer applications may provide sufficient reason for continued support of $\S 310(d)$, an exception for nonduplicated format cases would not neutralize the rule.

141 Changes in the Entertainment Formats of Broadcast Stations (Notice of Inquiry), 57 F.C.C.2d 580, 598-99 (1976) (Robinson, Comm'r, concurring). Commissioner Robinson analogizes the imposition of unequal financial burdens to "Caliban on Setebos" from the poem by Browning, who lets "twenty pass and stone[s] the twenty-first/Loving not, hating not, just choosing so."

142 See generally J. GrundFest, supra note 134. Grundfest's identification of the variables involved in citizens' petitions to deny and his economic analysis of their relationship serve as a foundation for the economic model presented here. 


\section{Costs}

Litigation costs associated with an application challenge occur at four stages: (A) the citizen group's decision to file; (B) the FCC's internal hearing and decision-making process; (C) the judicial appeal from the Commission's decision; and (D) the final outcome of the litigation process. ${ }^{143}$ In the format context, a citizen challenge ordinarily takes the form of a petition to deny renewal of a station's license in a situation in which the terms of renewal involve a format change ${ }^{144}$ or a petition filed in opposition to an application for license transfer in a situation in which the transferee contemplates a format change, as was involved in WEFM. ${ }^{145}$

To develop the model it is necessary to consider the probability that costs will be incurred at each stage of the process. Initially, when a challenging petition is filed, the broadcaster will incur legal fees in responding "with a probability of one-they are a certainty." ${ }^{146}$ If $x$ denotes litigation costs and a subscript the stage at which the costs are incurred, the licensee's cost of replying to the petition is $x_{A}$, representing the sum of the legal fees plus management and station personnel time expended during the first phase. ${ }^{147}$ In addition, because a shared format compromise reached early would have left part of the programming day for the proposed, and presumably more lucrative, format, the licensee's costs during this period must also include the cost of operating the current format.

If the matter is subsequently set down for adjudicative hearing, the applicant can expect to incur litigation costs of $x_{B}$. The signature gathering provisions of section (1)(B) (ii), which are modeled after state initiative laws ${ }^{148}$ and include a means to communicate with potential signers, provide a non-content-oriented, objective method to determine when the FCC should grant a hearing. Until these procedures are completed, however, the broadcaster is uncertain whether the matter will be forced to a hearing. ${ }^{149}$ Let $p_{B}$ be

143 Id. 178-82. "The model could be expanded to include the possibility of 'pre-filing' settlements but again the notation would be made more complex and the substantive results would be unaffected." Id. 179 n.2.

14447 U.S.C. $\$ \$ 307(d), 309$ (d) (I) (1970).

14547 U.S.C. $\$ 310$ (d) (Supp. V 1975). If a licensee alters the format during the license term not in connection with an assignment or transfer application, notice to the FCC is required but its approval is not. The change could bear, however, on the FCC's decision whether to renew the license. See Citizens Comm. to Preserve the "Voice of the Arts in Atlanta on WGKA-AM and FM" v. FCC, 436 F.2d 263, 272 (D.C. Cir. 1970).

$146 \mathrm{~J}$. GRUNDFEST, supra note 134, at 179.

147 Id. 180.

148 See, e.g., Cax. Elec. Code $\$ 3516$ (West 1977).

149 Even if the petitioners withdraw or fail to collect the required number of signatures, the FCC's Broadcast Bureau may enter the case and prosecute the objection in their stead. See 47 C.F.R. $\$ \$ 0.71,0.72$ (1977). 
the estimated probability that the complaint will reach this second phase.

Should the matter proceed beyond an FCG hearing, the applicant can expect litigation costs of $x_{o}$, with a probabilistic estimate of the controversy reaching stage three of $p_{o}$. Finally, if the petition is successful, the broadcaster could lose the benefits requested in its application. In a transfer situation governed by section 310(d) of the Act, ${ }^{150}$ a successful challenge would return conditions to those existing before the application was filed. Moreover, if a sale of the broadcast property was conditioned upon obtaining format change approval the sale would effectively be aborted by a successful challenge. The broadcaster's defeat in the context of a license renewal application could mean a loss equal to the value of the station's frequency rents plus whatever value the broadcaster places on holding the license. The cost of losing the benefits requested in either a transfer or renewal application is denoted as $x_{D}$, with $p_{D}$ representing the estimated probability of either of these events occurring.

Thus, when an opposing petition is filed, an applicant who is challenged can approximate the costs that will be incurred if compromise is not reached by taking the sum of legal fees, lost station personnel time, and the profits foregone by having to maintain the old format at each stage of litigation, multiplied by the probability of the controversy reaching that stage. To that is added the probability of eventually failing to obtain a license renewal or other benefit (in particular, completion of the sale) connected with the format change request, multiplied by the value placed on those benefits. Finally, the costs of any delay resulting from the challenge must be added. These include freezing of other projects and the use of capital until the challenge is resolved, as well as the adverse effects on the licensee's ability to raise capital during the pendency of the litigation. If these costs are labeled $e$, and total aggregate costs to the broadcaster of litigating are labeled $G$, then

$$
C=x_{A}+p_{B} x_{B}+p_{O} x_{C}+p_{D} x_{D}+e . .^{151}
$$

\section{Benefits}

An applicant should be willing to agree to a subformat compromise if litigation costs exceed the difference between (l) the

15047 U.S.C. $\$ 310$ (d) (Supp. V 1975).

151 See J. GRUNDFEST, supra note 134, at 181: "Since the litigation process is spread over time, the broadcaster will discount the actual costs he expects to incur to yield estimates of $\left[x_{b}, x_{0}\right.$, and $\left.x_{D}\right]$. Thus, it is implicit that the broadcaster is 
expected benefits from the new format and (2) FCC incentive benefits granted to a licensee who reaches a compromise over the format change.

Benefits from not settling. Two benefits accrue to an applicant who obtains approval to change from a less profitable to a prospectively more profitable format: larger advertising profits and an increased station market value. If $F_{8}$ represents anticipated advertising profits from a negotiated, subformat approach and $F_{n}$ the profits anticipated from the proposed format, then $F_{n}$ $F_{s}=F$ measures the additional profits gained by failure to compromise and eventual success through litigation. In addition, if it is assumed that the new format will make the station more profitable than before, the station's value will also increase. Let $L$ represent the increment in market value of the station that results from the change in format. ${ }^{152}$ Thus, $F$ plus $L$ constitutes the benefits accruing to the licensee by uncompromising and successful opposition to a petitioner's challenge.

Benefits from settlement. To encourage prehearing format settlements, the FCC could reduce, directly and indirectly, the legal and administrative expenses borne by the challenged licensee. First, the Commission could grant to a licensee who had reached a settlement a presumption of meritorious programming practices for the forthcoming licensing period. ${ }^{153}$ Although such a preference would

also making an estimate of how long it will take to reach each stage of litigation in order to arrive at an expression such as [the equation in the text]." Id. I8I n.2.

152 The applicant cannot expect to acquire the full value of $L$ at the time of the transfer. Indeed, to the extent the premium value of a license with the proposed new format is known, it would presumably be incorporated into the purchase price by the current licensee.

${ }^{153}$ Although the Commission has never clearly articulated the requirements for designating program service as "superior," it is clear that the FCC views such criteria as useful tools in the license renewal process. See, e.g., Cowles Fla. Broadcasting Inc., 60 F.C.C.2d 372 (1976), clarified, 62 F.C.C.2d 953 (1977), vacated and remanded sub nom. Central Fla. Enterprises, Inc. v. FCC, No. 76-1742 (D.C. Cir. Sept. 25, 1978). In Cowles, the FCC granted a Daytona Beach television license to the renewal applicant even though a competing new applicant had a clear preference under the "diversification of media ownership" criterion. The Commission based its decision on the incumbent's performance under the "best practicable service" test. Under that approach, the renewing licensee was awarded a preference for "superior" performance, in spite of the finding by the administrative law judge that the programming was "thoroughly acceptable" but not "superior." The clarifying opinion in Cowles stated that special consideration of a licensee's performance must be based on a finding of "sound," "substantial," or "favorable" performance. 62 F.C.C.2d at 955-56. In vacating the Commission's decision, the Court of Appeals for the District of Columbia Circuit found the prior decision in favor of the incumbent to be a "puzzling result," one appearing "more bizarre as it is thought about." Slip op. at 30 .

The FCC's most extensive attempt to create a policy assuring renewal to incumbent licensees whose past programming performance was deemed "superior" culminated in the 1970 Policy Statement Concerning Comparative Hearings Involving 
not immunize an applicant from all attack (for instance, discriminatory employment practices would be a ground to deny a pending application), the presumption would place a station's programming beyond the not insignificant attacks for failure to program in the public interest. ${ }^{154}$ Thus, the litigation cost of the next renewal could be reduced by $R$, representing the value of this presumption to the broadcaster.

A second way in which the FCC could employ its administrative powers to foster voluntary settlements would be by deregulating the renewal process. By hypothesis, a negotiated shared format package should reflect the needs and desires of a significant portion of the station's listening public. Hence, requiring a licensee who has reached a settlement to conduct extensive community-wide ascertainment (generally speaking, a survey of the needs and interests of the public served by the licensee to be used in program formulation) is somewhat superfluous because it has already committed a substantial time block to a recognized programming need. Accordingly, if the licensee consents to a shared format, the FCC could excuse him from certain costly, time-consuming ascertainment requirements as it already has done in some respects for stations in smaller communities. ${ }^{155}$ Implementation of this simplified filing

Regular Renewal Applicants, 22 F.C.C.2d 424 (1970), which provided that renewal would be granted "if the applicant for renewal of license shows in a hearing with a competing applicant that its program service during the preceding license term has been substantially attuned to meeting the needs and interests of its area, and that the operation of the station has not otherwise been characterized by serious deficiencies." Id. 425 (footnotes omitted). The Court of Appeals for the District of Columbia Circuit subsequently nullified the FCC statement in Citizens Communication Center v. FCC, 447 F.2d 1201 (D.C. Cir. 1971), on the ground that it violated $\S 309$ (e) of the Communications Act of 1934. See Brenner, Toward A New Balance in License Renewals, $17 \mathrm{~J}$. Broadcasting 63, 71 (1972-73); cf. Formulation of Policies Relating to the Broadcast Renewal Applicant, Stemming from the Comparative Hearing Process, 66 F.C.C.2d 419 (1977) (Commission rejects percentage standard for news and public affairs programming minima), aff'd sub nom. National Black Media Coalition v. FCC, No. 77-1500 (D.C. Cir. Oct. 13, 1978).

154 See cases cited in Brenner, supra note 100, at 59 n.136.

155 Ascertainment of Community Problems by Broadcast Applicants, 57 F.C.C.2d $418,419,435=39$ (1976), -exempts broadcasters situated in communities with populations of 10,000 or less that are located outside all officially designated standard metropolitan statistical areas from FCC ascertainment requirements. Although "still required to remain conversant with community problems," id. 419 , small market licensees are "exempt from all Commission inquiry into the manner in which they become aware of community problems and needs," id. 435, based on the premise that "the broadcaster in the smaller community knows his town thoroughly, not only its majorities but also its minority elements." Id. (quoting Ascertainment of Community Problems by Broadcast Applicants) (Further Notice of Inquiry and Proposed Rulemaking), 53 F.C.C.2d 3, 28 (1973). Under the 1976 ascertainment primer, every licensee not exempt under the "small market" exception, must: (1) prepare a list of the demographic aspects of the city of license, including population figures, numbers and proportions of males, females, youth, minorities, and the elderly; (2) 
requirement will result in reduced legal fees and reduction of the time spent by management and station personnel ascertaining the community's problems from community leaders and the general public. Let $D$ represent these deregulation savings.

Third, the Commission could waive its nonduplication rule for an AM/FM combination licensee who agrees to maintain a nonduplicated format on one station. ${ }^{156}$ Although not always applicable, such a waiver, granted when continued viability of station operation would otherwise be in doubt, is an incentive with potential value for some licensees that does not involve the Commission in a direct review of content. Designate its value, if any, as $W$.

Fourth, the Commission could give a flat monetary discount to a compromising licensee on fees due the FCG. This discount may pose first amendment problems because it suggests a government subsidy for "preferred" speech. However, these infirmities are overcome if it is recognized that the subsidy in question actually forestalls the limitation of another "voice" in the marketplace, a result consistent with the first amendment even if not a demonstrable addition to listener satisfaction. Its reasonableness is further evidenced by the potential savings to the FCG from the preemption of a lengthy format inquiry. The Commission's citation of its own

conduct face-to-face and other interviews with leaders of institutions in the community and submit a tally of those interviews with its application for license renewal; (3) prepare annually a list of no more than ten problems discovered in the community and programming designed to meet them; and (4) conduct a general public survey of the community, which includes the results as well as a narrative statement describing how the public survey was taken. Noncommercial broadcasters are also subject to formal ascertainment requirements. Ascertainment of Community Problems by Noncommercial Educational Broadcast Applicants, 54 F.C.C.2d 766, 775 (1975).

The FCC's rationale for the small market exception-that smaller community broadcasters know their communities-would apply to the exemption from ascertainment proposed in this Article. Although the city of license may be large, the relevant community for a specialized, nonduplicated format is its audience. By the process of negotiating a settlement that provides programming for this relevant market, the licensee can be deemed to know its "community" as well as any small market licensee.

Under $\$ 434$ of the proposed Communications Act of 1978, H.R. 13015, 95th Cong., 2d Sess. $\$ 434$ (1978) (introduced at 124 Cong. Rec. H5128 (June 7, 1978)), the Communications Regulatory Commission, the successor to the FCC, would be prohibited from establishing a procedure requiring that television broadcast stations perform ascertainment.

156 See 47 C.F.R. $\$ 73.242$ (1977). It is arguable that if an additional incentive is needed to induce agreement, the Commission might conclude that a station be excluded from fairness doctrine obligations as well as from the general duty to cover public affairs and news, provided that it reaches settlement. Cf. H.R. 13015, 95th Cong., 2d Sess. $\$ 434$ (1978) (introduced at 124 CoNG. Rec. H5128 (June 7, 1978)) (would replace the faimess doctrine with an "equity principle," which requires some coverage of controversial issues, in an equitable manner). Although this presents a controversial proposition, it is arguable that a licensee providing a limited 
costs in the WEFM litigation suggests the economic value of such an inducement. Let $G$ represent the value of the discount. ${ }^{157}$

As previously noted, an applicant should be willing to settle rather than litigate whenever the litigation costs exceed the sum of the added profits and accretion to the value of the license resulting from the new format minus the benefits granted by the FCC for settling. ${ }^{158}$ Expressed as an equation, a settlement should occur whenever

$$
C>(F+L)-(R+D+W+G),
$$

appeal format is contributing its share to the community's broadcast mix, and the savings resulting from not having to maintain news or public affairs departments should be counted against the cost of a less profitable format.

A second additional incentive, directed toward the seller rather than the buyer, would be deferral of the taxable gains realized on the sale or exchange of the station pursuant to I.R.C. $\$ 1071$. The FCC is empowered to grant tax relief upon its certification that the sale or exchange is "necessary or appropriate to effectuate a change in a policy of, or the adoption of a new policy by, the Commission with respect to the ownership and control of radio broadcasting stations." The Commission has issued tax certificates to alleviate the hardship of an involuntary transfer resulting from forced divestiture under the agency's multiple ownership rules, as an incentive to force licensees to divest communications properties grandfathered under the multiple ownership rules, see Issuance of Tax Certificates, [1970] 19 RAD. REG. 2d ( $P$ \& F) 1831, and, recently, to foster the growth of minority ownership of broadcast facilities. Statement of Policy on Minority Ownership of Broadcast Facilities. [1978] 42 RAD. REG. 2d (P \& F) 1689. Although the seller obtains the tax benefit the buyer who obtains the benefit for the seller could recover its value by renegotiating the purchase price.

157 This fee discount would appear to be consistent with the guidelines set forth by the Court of Appeals for the District of Columbia Circuit in the 1976 fee assessment cases. Capital Cities Communications, Inc. v. FCC, 554 F.2d 1135 (D.C. Cir. 1976); National Ass'n of Broadcasters v. FCC, 554 F.2d 1118 (D.C. Cir. 1976); Electronic Industries Ass'n v. FCC, 554 F.2d 1109 (D.C. Cir. 1976); National Cable Television Ass'n, Inc. v. FCC, 554 F.2d 1094 (D.C. Cir. 1976). These cases arose from the FCC's failure to adopt a policy (and provide refunds in accordance therewith) mandated by National Cable Television Ass'n v. United States, 415 U.S. 336,341 (1974). National Cable invalidated a cable television annual fee that was not based entirely on the "value to the recipient" but included fees based on the cost of services that inured to the benefit of the public generally, in violation of the Independent Offices Appropriation Act of 1952, 31 U.S.C. $\$ 483 a$ (1976). See FPC v. New England Power Co., 415 U.S. 345 (1974). The court of appeals' fee guidelines require the Commission

to identify the specific items of direct or indirect cost incurred in providing each service or benefit for which it seeks to assess a fee, and then to divide the cost among the members of the recipient class . . . in such a way as to assess each a fee which is roughly proportional to the "value" which that member has thereby received.

National Cable, 554 F.2d at 1105-06 (footnote omitted). Because a compromising licensee will be conserving the Commission's time and resources by terminating the format dispute at its inception, it will belong to a class of licensees whose licenses will be less costly for the FCC to administer. The exact percentage discount would be computed by the Commission and inserted into subsection $3(\mathrm{~b})$ of the proposed regulation. In order to foster settlements, the FCC could also consider granting a "bonus" discount unrelated to its actual costs. See note 159 infra.

158 Of course, an applicant may be unwilling to compromise at any cost, because of its commitment to the first amendment interests that may have motivated it to ini- 
where $R, D, W$, and $G$ represent the benefits conferred by the FCC for format compromise, $F$ plus $L$ represents the benefits from not settling and prevailing through the appeal, and $C$ represents the costs incurred by the licensee in the course of trying to obtain a changed format. If the terms of the equation are rearranged, the proposed solution should encourage voluntary settlement whenever

$$
R+D+W+G>(F+L)-G \text {. }
$$

It becomes clear that in order to foster settlement $R$, the value of the programming presumption, $D$, the elimination of ascertainment costs, $W$, the value of a nonduplication waiver, and $G$, the discount applied to FCC fees, need only be adjusted so that together they just exceed the difference between $C$ and $(F+L)$, based on the assumption, of course, that the reward, $(F+L)$, is at least worth the effort, $C$. These adjustments are embodied in the FCC's power to grant ascertainment waiver extensions provided in section (3)(B) and to set a fee discount in (3) (D). ${ }^{159}$

\section{F. Evaluation of the Proposed Solution}

\section{Operational Aspects}

Each variable in the model operates in a distinct way. After a particular litigation stage, the related component of the broadcaster's costs, $C$, are sunk and unrecoverable. These costs are onetime expenditures and upon final approval of the desired format change, the station will not be subject to further attack for failing to carry the old format. In contrast, the four incentive variables $(R, D, W$, and $G)$ will vary over time. The margin of safety pro-

tiate the format change in the first place. The Supreme Court has recognized a broadcaster's complete editorial discretion over some matters. In CBS v. Democratic Nat'l Comm., 412 U.S. 94 (1973), the Court held that a broadcaster had an absolute right to refuse to accept editorial advertising, as long as the fairness doctrine (requiring the presentation of contrasting viewpoints on issues of public importance) was enforced by the FCC. It is not clear, however, that this discretion should extend to choice of format in situations in which the interests of listeners predominate over those of broadcasters. See notes 103-14 supra \& accompanying text.

159 National Cable Television Ass'n, Inc. v. FCC, 554 F.2d 1094 (D.C. Cir. 1976), and its companion cases, see note 157 supra, prohibit the FCC from charging a fee not attributable to costs incurred in administering the license. That rule, however, does not seem to enjoin the Commission from refusing to charge a fee for certain desired licensee conduct, provided that the remaining licensees do not have to subsidize the fees not charged. Of course, not all of the Commission's activities are paid for by fees charged to licensees; if it is assumed that the public interest is served by the subformat proposal advocated in this Article, it does not seem improper to allow the FCC to bear these incentive costs out of funds allocated by Congress. Because the settlement rate should increase, the FCC should experience declining administrative costs that will offset the costs of those incentives. 
vided by a responsive programming determination at renewal time increases as the license's value increases. ${ }^{160}$ Furthermore, the importance of compliance with administrative formalities will vary directly with the value of a station. Thus, the greater the value of the station to the licensee, the greater the value of $D$, and, possibly, $W$. $G$ varies as administrative costs vary.

The value of factor $F$, representing the added profits that would accrue to the licensee if there were no settlement, depends upon the terms of the compromise struck by the citizens group and the broadcaster, which are embodied in $F_{s}$. The predicted values of $F$ and $L$ (the increase in market value without settling) will diminish the more that one expects post-settlement carriage of the new format to increase the audience of the station, and, accordingly, its market value. In particular, the difference, $F$, presumably will be smaller when a larger proportion of the broadcast day is dedicated to the new format. Costs may be associated with attracting different kinds of advertisers and audiences, however, that will require a minimum number of hours to be allocated to each format in order to make the combined format economically viable. In addition, production costs may dictate an absolute minimum for each subformat. For instance, a station currently programming all news may require a second studio in order to produce a progressive rock format, which would thereby justify apportionment of substantial time to that format to defer those fixed costs. The value of $F$ thus depends on the percentage of broadcast time allocated to each format after compromise; the likelihood of compromise in turn depends upon how resolute each side remains. Whether the dispute will erupt into litigation depends upon whether the challenger's initial minimum demand exceeds the station's maximium offer, and if so, whether the gap separating them can be closed. If the citizens' group refuses any compromise and meets the hearing requirement,

160 If the petition challenges a format change pursuant to a renewal application, the fourth stage of litigation costs, $p_{D} x_{D}$, and the value of the renewal preference, $R$, will be minimal, based on past precedent. In the last 40 years, only two broadcast licensees have lost their licenses as a result of petitions to deny. See Office of Communication of United Church of Christ v. FCC, 425 F.2d 543 (D.C. Cir. 1969); Alabama Educ. Television Comm'n, 50 F.C.C.2d 461 (1975). The precedential value of these cases for predicting FCC renewal activity is negligible because the offending practices in both cases involved blatant race discrimination. The number of license renewals set for hearing as a result of petitions to deny is "something like ten in the entire history of American broadcasting." Remarks of Cong. Torbert MacDonald, National Association of Broadcaster's Convention, Chicago, Ill. (Mar. 23, 1976), reported in Broadcasting, Mar. 29, 1976, at 34. The industry's renewal record is nearly perfect, as $99.32 \%$ of all applications for renewal were granted in $1972,99.10 \%$ in 1973, and $99.69 \%$ in 1974. Id. Hence, while the costs of rebuffing challengers may be high, their chances for success are slim. 
unless the applicant withdraws its plans, the parties can expect to litigate through the court of appeals stage. ${ }^{101}$

Litigation costs, $C$, play an important role in the equation, but they are not susceptible to easy determination, in part because of the probabilistic estimates associated with each phase, and in part because figures illustrating past costs are not generally available. Nonetheless, some data suggest that legal fees in excess of $\$ 100,000$ are not unusual for citizen-broadcaster controversies, and a case that proceeds through numerous appeals reportedly can cost a broadcaster in excess of $\$ 1,500,000.162$

\section{Advantages}

One of the proposal's advantages is its tendency to telescope "public grumbling" and thereby satisfy the most visible sources of discontent accompanying a format change. For instance, if the Committee's members in WEFM listened to WEFM during daytime hours more than at night, the broadcaster might have retained the original format during these critical hours of service and have allocated the rest of the day to the more profitable program format. ${ }^{163}$

This proposal also avoids a potential pitfall with a settlementoriented model-bribe payments by broadcasters to quiet challengers. If the amount of an effective payoff is less than the litigation costs, and the values of the other variables are either

181 An example of the untiring citizen intervenor is found in the effort by Accuracy in Media (AIM) to obtain a determination that NBC violated the fairness doctrine by broadcasting a documentary on pensions in the United States. See NBC v. FCC, 516 F.2d 1101 (D.C. Cir. 1974), vacated as moot, 516 F.2d 1180 (D.C. Cir. 1975), cert. denied, 424 U.S. 910 (1976).

$162 \mathrm{~J}$. GRUNDFEST, supra note 134, at 97-98. The high cost of format litigation was cited by the FCC as a reason for avoiding governmental regulation in the area. See Changes in the Entertainment Formats of Broadcast Stations, 66 F.C.C.2d 78, 82 (1977). According to the agreement filed with the Commission by GCC and the Citizens Committee in Citizens Comm. to Save WEFM v. FCC, 506 F.2d 246 (D.C. Cir. 1974), the citizen intervenors incurred legal fees amounting to $\$ 60,000$. See Schneyer, supra note 134, at 650.

163 For example, in Citizens Comm. to Save WEFM v. FCC, 506 F.2d 246 (D.C. Cir. 1974), paragraph five of the agreement between GCC and the Citizens Committee, see note 20 supra, included $\$ 12,000$ funding by GCC to staff an allnight classical music listening service on WBEZ-FM, a noncommercial station operated by the Chicago Board of Education. Prior to the agreement, WBEZ-FM had been broadcasting only children's and jazz programming 40 hours a week. This settlement provision suggests that late evening classical music service was of prominent importance to the intervenors. Cf. WNCN Listeners Guild, 48 F.C.C.2d 36 (1974) (fairness doctrine complaint regarding a classical music station's own broadcast announcements urging creation of a listener-sponsored, noncommercial station to fill void created by its own format abandonment). 
unascertainable or roughly cancel each other out, then that payoff would be economically advantageous to the broadcaster. Sections (4) and (5) of the proposal prohibit their use..$^{164}$

Indeed, this scheme tests the depth of any merit goods claim made by the petitioner and assists the FCC in formulating its own judgment. First, the pre-hearing petitioning effort must reveal that a sufficiently substantial part of the audience of the core city of license objects to the format loss. Second, the citizens' allegation that a format deserves merit goods treatment because it has significant impact on values or needs of the community will likely. fall on increasingly deaf ears at an administrative hearing as greater portions of the broadcast day are claimed. Groups conscious of this likelihood will probably temper their demands to avoid diminution of their bargaining tokens, namely the pre-hearing rewards available to the station as settlement incentives. Additionally, by overzealousness the group may lose credibility in the eyes of the Commission, the members of which may eventually have to make a merit goods judgment.

Of course, a broadcast applicant need not settle, even if a nonduplicated format is about to disappear. In the event that the citizens group and broadcaster do not reach a compromise, the ensuing hearing will enable more informed decision-making by the Commission. Affidavits and listener surveys placed into the record demonstrating insignificant community interest in perpetuating a particular format, proof of insolvency if the current format is retained, and evidence of alternative public sources for the abandoned programming (e.g., libraries and community concerts) will serve as additional aids to the FCG in deciding whether the format deserves merit goods treatment.

Finally, if the matter proceeds to hearing, the proposal gives the FCC usable data to evaluate the broadcaster's claims of financial losses due to the current format by eliciting from the parties their proposals for compromise on the change. The agency can examine the offers of each side in the context of station size and resources. At the hearing, the FCC can suggest, but not impose, a shared format compromise that might satisfy both parties. By emphasizing negotiation, the FCC avoids the "sudden death" climate-of either

164 Should a bribe actually be paid, the FCC can punish the applicant by considering the bribe indicative of the broadcaster's character at renewal time or by directing the Broadcast Bureau to study the possibility of independently opposing the format change. See 47 C.F.R. $\$ 0.71$ (1977). Any agreement would also be subject to the Commission's citizen agreement guidelines. See Agreements Between Broadcast Licensees and the Public, 57 F.C.C.2d 42 (1975). 
station or format-that permeates the all-or-nothing regulatory solutions suggested in the WEFM case. ${ }^{165}$

The envisioned approach requires the intervenor to come forward at the hearing with the shared format proposal it had offered during negotiations but which the applicant had rejected. The proposal would concentrate retention of the current format during the hours most crucial to the merit goods role played by the format. The burden of proof that a format is not duplicated would rest with the intervenors. The vexatious issue of format definition does not evanesce entirely, but its prominence diminishes because the burden of showing nonduplication could be met through the submission of affidavits of program directors at other stations which state that the applicant's format does not duplicate theirs, or through submission of studies (prepared by intervenors) that monitor the programming of the market's stations.

A citizens group would, of course, be free to insist on retention of the entire format, but their proposal would have to be accompanied by a statement of reasons why the hours claimed would serve their particular programming needs. Once the petitioners make such a presentation, the burden shifts to the applicant to show reasons why the proposed shared format arrangement would not reverse the station's financial situation. This could be done, for example, by showing that the current format's demographic appeal

165 An eloquent critique of the "all-or-nothing" perspective and the place of subformats can be found in the initial decision of the administrative law judge in Simon Geller, Mimeo No. 1665, Docket No. 21104 (June 6, 1978). This proceeding involved mutually exclusive applications for an FM frequency in Gloucester, Massachusetts. The renewal applicant, Simon Geller, operated WVCA-FM singlehandedly, with almost exclusively music programming and a minimal provision for news and public affairs programs. The other applicant, Grandbanke Corporation, applied for a construction permit to operate in Gloucester on the same frequency. The administrative law judge concluded that Geller should be assigned the frequency, based in large part on past service, even though Grandbanke was thoroughly qualified and formulated a more well-rounded proposal, which included extensive news and public service programming. In so deciding, however, tho administrative law judge stated:

Since Geller is on the air for the minimum number of hours permitted by the Commission's rules, and has in fact sought a waiver to allow occasional departures from this requirement, a shared use of the frequency by both Grandbanke and Geller would seem the ideal solution to the case. The presiding officer strongly urges that the parties consider this alternative and recommends that should an accommodation be reached the Commission look upon it with favor.

Id., slip op. at 24. Having recognized that "[i]t is unfortunate that a choice must be made between these applicants," id., the administrative law judge urged the parties to develop inter se a sharing of formats-Geller's pure classical and Grandbanke's public affairs and mixed-music format. Although developed in a comparative hearing context, the approach urged in Simon Geller harmonizes with the direction of the regulations proposed in this Article. 
is unattractive to a sufficient number of listeners and unprofitable even under a subformat arrangement.

The thrust of the suggested procedure is thus directed away from the difficult question whether a format should be eliminated entirely and directs the parties toward the issue of why the proposed transferee could not program a designated proportion of its schedule with the current format and use the remainder of the broadcast day for its proposed format. As the share claimed by petitioners grows closer to $100 \%$, their burden of showing special need for retaining the format would grow. Only if both sides remained intransigent would the FCG be required to intervene, make a merit goods judgment, and declare a victor. Under this mandate, the FCG would not attempt to divide the station's programming day on its own. Common sense suggests that stubborn refusal by one side in the face of a reasonable format division by the other will be hard to justify and will reflect adversely on the party's sensitivity to the public interest.

The FCC could, of course, grant a format change request if the station's continued financial operation of the old format would imperil its future operations. In making a merit goods judgment, the Commission would give substantial weight to the broadcaster's desire to change formats and consider in its decision the unequal position that the applicant occupies in comparison to those broadcasters already airing the proposed format. Thus, while this proposal does not go as far as the Format Policy Statement which virtually abdicates the regulatory function of the FCG in format challenges, it assures that merit goods determinations will be made with considerable deference to broadcasters whose decision to change formats is the result of a reasonable business judgment.

One final advantage of this proposal, from the perspective of fostering informed agency rulemaking, is its adaptability to empirical testing before its adoption. This evaluation can be accomplished by Commission substitution of data relating to recent format controversies (obtained on a confidential basis) for the variables in the model on which the proposal is based. Such testing would reveal whether the benefits conferred by the FCC plus the savings in litigation costs can be expected to exceed the anticipated benefits of refusing to settle.

\section{Conclusion}

The proposal outlined in this Article seeks to encourage compromise in transfer application challenges involving nonduplicated 
radio formats. By adding significant administrative incentives to the savings in litigation costs of a licensee who reaches settlement, the Commission can increase the likelihood of pre-hearing settlements between the parties. Only when compromise is not reached will the FCC be forced to deviate from its constitutional preference for non-interference in station programming and evaluate the merit goods claims of petitioners.

Admittedly, this proposal does not cure all of the problems raised by challenges to format changes. First, the intractable problem of operationally defining "format" is not eliminated, only deemphasized. Second, the proposal injects a dose of burdensome regulation into the bloodstream of a licensee who is allegedly in financial distress because of its current format, which may cause delays and make it more difficult to find a transferee for the broadcast property. Third, the proposal summons the FCC to intrude into programming operations of stations with little more than its intuition about merit goods as a guide.

Yet the necessary predicate for committing the process to a station's vision of what the marketplace wants-a direct method of registering preference intensities-is absent. Leaving format decisions to the indirect regulation of advertisers on the one hand allows demographically attractive audiences literally to call the tunes and on the other rejects the legitimate characterization of some programming as a form of merit good.

The foregoing proposal offers a species of regulation poised in between the extremes set forth by the Court of Appeals for the District of Columbia Circuit and the Commission. The program choices of listeners will not routinely be dependent upon the government's format preferences, but neither are they left wholly to indirect regulation by advertisers. Instead, this Article advocates a system under which the Commission retains the ultimate authority to characterize some programming as a form of merit good in format cases, but which facilitates resolution of most cases through the availability of non-content-related administrative incentives. This system of offering non-content-related incentives to induce settlement accurately reflects the needs of an advertiser-oriented marketplace of radio broadcasting in the United States as well as the competing first amendment interests at stake in format controversies. The proposed regulation-or any other settlement-oriented approach-therefore provides a realistic starting place to address the hard issues encountered in format change cases. 